\title{
Transferring Building Energy Technologies by Linking Government and Private-Sector Programs
}

\author{
Barbara C. Farhar
}

July 1990

Prepared under Task No. AS925440

Solar Energy Research Institute

A Division of Midwest Research Institute

1617 Cole Boulevard

Golden, Colorado 80401-3393

Prepared for the

U.S. Department of Energy

Contract No. DE-AC02-83CH10093 


\section{NOTICE}

This report was prepared as an account of work sponsored by an agency of the United States government. Neither the United States government nor any agency thereof, nor any of their employees, makes any warranty, express or implied, or assumes any legal liability or responsibility for the accuracy, completeness, or usefulness of any information, apparatus, product, or process disclosed, or represents that its use would not infringe privately owned rights. Reference herein to any specific commercial product, process, or service by trade name, trademark, manufacturer, or otherwise does not necessarily constitute or imply its endorsement, recommendation, or favoring by the United States government or any agency thereof. The views and opinions of authors expressed herein do not necessarily state or reflect those of the United States government or any agency thereof.

Printed in the United States of America

Available from:

National Technical Information Service

U.S. Department of Commerce

5285 Port Royal Road

Springfield, VA 22161

Price: Microfiche A01

Printed Copy A04

Codes are used for pricing all publications. The code is determined by the number of pages in the publication. Information pertaining to the pricing codes can be found in the current issue of the following publications which are generally available in most libraries: Energy Research Abstracts (ERA); Government Reports Announcements and Index (GRA and I); Scientific and TechnicalAbstract Reports (STAR); and publication NTIS-PR-360 available from NTIS at the above address. 


\section{PREFACE}

On April 19, 1990, the Assistant Secretary for Conservation and Renewable Energy (CE), J. Michael Davis, announced a reorganization of his office within the U.S. Department of Energy (DOE). The Office of Building and Community Systems (OBCS), for which the study resulting in this report was conducted, was replaced by an Office of Building Technologies (OBT), headed by Deputy Assistant Secretary John P. Millhone. Within OBT, three offices now exist: (1) the Office of Buildings Energy Research (OBER), (2) the Office of Codes and Standards (OCS), and (3) the Office of the Federal Energy Management Program (FEMP).

The results of the planning effort described in this report and in the comprehensive report on the entire study (B.C. Farhar et al., A Planning Framework for Transferring Building Energy Technologies, SERI/TP-260-3729) apply to OBT programs in a crosscutting sense. Technology transfer functions may, in the future, be located in a different unit within the CE organization as a result of the reorganization; however, the recommendations of this report apply regardless of the organizational unit in which technology transfer functions reside. Therefore, references to the building-energy-efficiency R\&D program are now made by referring to OBT and are intended, in general, to include the crosscutting aspects of technology transfer for that program.

The Office of State and Local Assistance Programs (OSLAP), also mentioned in this study, was included in the CE reorganization at DOE. In its stead, an Office of Technical and Financial Assistance (OTFA) has been formed. Three offices report to Frank Stewart, the Deputy Assistant Secretary for Technical and Financial Assistance: (1) The Office of National Programs, including the Energy-Related Inventions Program (ERIP); (2) the Office of Grants Management, including the Weatherization Assistance Program (WAP) and the Institutional Conservation Program (ICP); and (3) the Office of Technical Assistance, incorporating federal information programs.

A DOE and U.S. Department of Housing and Urban Development (HUD) joint initiative is another significant development relevant to the study. The potential for joint DOE-HUD activities is explored in this report. The agencies currently plan to work together to save energy and improve comfort in a wide range of HUD programs mentioned in this report. The joint initiative is expected to reduce federal expenditures for energy and reduce emissions of gases damaging to the environment. A 25\% energy savings in public housing nationwide, for example, could provide savings of approximately $\$ 200$ million while increasing occupants' comfort. Emissions could be reduced by more than 3 million tons of carbon dioxide, 8,000 tons of sulfur dioxide, and 5,000 tons of nitrogen oxides. The DOEHUD agreement was put in motion by an exchange of letters between W. Henson Moore, Deputy Secretary, DOE, and Jack Kemp, Secretary, HUD. The cooperative program will be directed by J. Michael Davis, DOE, and Anna Kondratas, Assistant Secretary, Community Planning and Development, HUD.

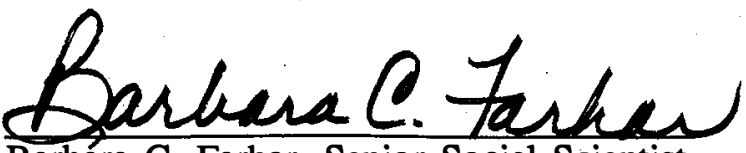

Barbara C. Farhar, Senior Social Scientist

Energy and Environmental Analysis

Division

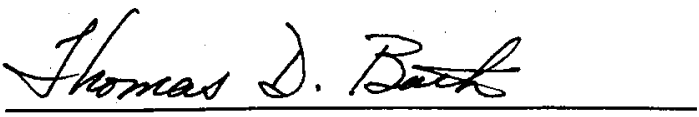

Thomas D. Bath, Director

Energy and Environmental Analysis Division 


\section{CONTENTS}

$\underline{\text { Page }}$

Introduction $\quad 1$

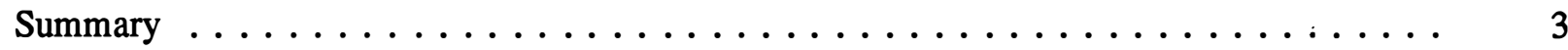

DOE Programs

Office of Technical and Financial Assistance (OTFA) $\ldots \ldots \ldots \ldots \ldots$

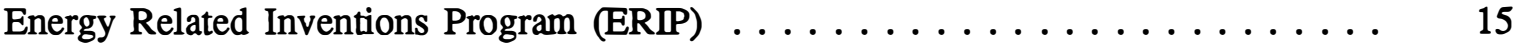

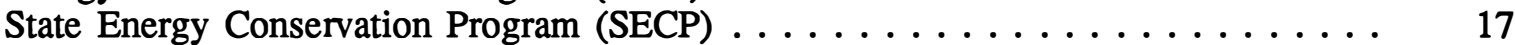

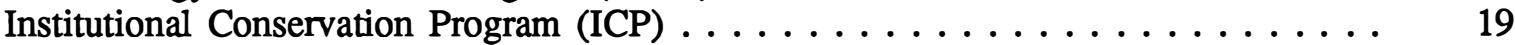

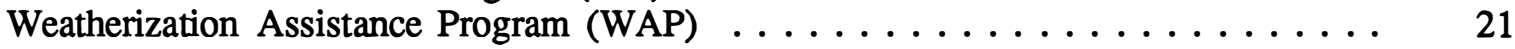

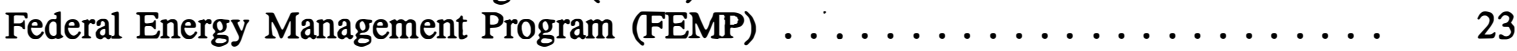

Small Business Innovation Research (SBIR) . . . . . . . . . . . . . . . . 25

Information Services

Conservation and Renewable Energy Inquiry and Referral

Service (CAREIRS) . . . . . . . . . . . . . . . . . . . . . . . 29

National Appropriate Technology Assistance Service (NATAS) . . . . . . . . . . 31

Solar Technical Information Program (STIP) $\ldots \ldots \ldots \ldots \ldots \ldots \ldots \ldots$

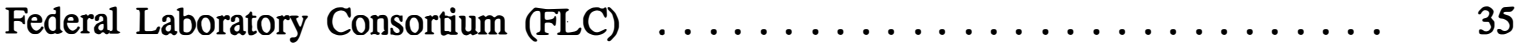

Other Federal Programs

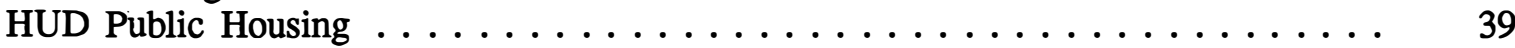

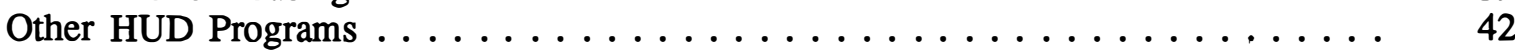

National Institute of Standards and Technology (NIST) . . . . . . . . . . . . 45

Trade and Professional Organizations

National Association of Regulatory Utility Commissioners (NARUC) . . . . . . . . 51

National Association of State Energy Officials (NASEO) $\ldots \ldots \ldots \ldots \ldots \ldots$

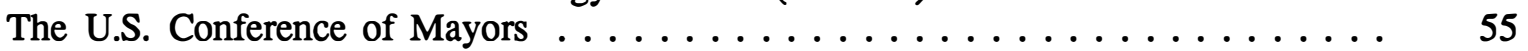

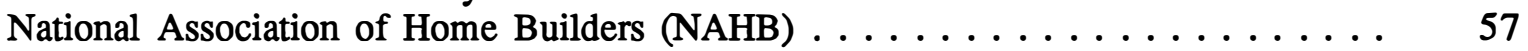

NAHB National Research Center . . . . . . . . . . . . . . . . . . . . . 59

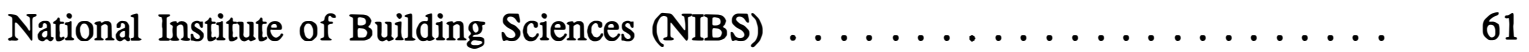

Building Thermal Envelope Coordinating Council (BTECC) . . . . . . . . . . 63 


\section{GLOSSARY}

\begin{tabular}{|c|c|}
\hline Acronym & Stands for \\
\hline ACEC & American Consulting Engineers Council \\
\hline ACSA & Association of Collegiate Schools of Architecture \\
\hline AGA & American Gas Association \\
\hline AHAM & Association of Home Appliance Manufacturers \\
\hline ASEAM & A Simplified Energy Analysis Method \\
\hline ASHRAE & American Society of Heating, Refrigerating, and Air-Conditioning Engineers \\
\hline ASTM & American Society for Testing and Materials \\
\hline BCS & Office of Buildings and Community System \\
\hline BEAS & Building Energy Accounting System \\
\hline BECA & Building Energy-Use Compilation and Analysis \\
\hline BEP & Building Energy Programs \\
\hline BET & Building Energy Technology \\
\hline BTECC & Building Thermal Envelope Coordinating Council \\
\hline BTESM & Building Thermal Envelope Systems and Materials \\
\hline CADDET & Center for the Analysis and Dissemination of Demonstrated Energy Technologies \\
\hline CAREIRS & Conservation and Renewable Energy Inquiry and Referral Service \\
\hline CBT & Center for Building Technology (within NIST) \\
\hline $\mathrm{CCB}$ & Construction Criteria Base (within NIBS) \\
\hline CDBG & Community Development Block Grant \\
\hline $\mathrm{CE}$ & Office of Conservation and Renewable Energy (within DOE) \\
\hline CLPHA & Council of Large Public Housing Authorities \\
\hline $\mathrm{DOC}$ & Department of Commerce \\
\hline DOD & Department of Defense \\
\hline DOE & Department of Energy \\
\hline DSM & demand-side management \\
\hline EBER & Existing Buildings Efficiency Research (formerly a BCS program) \\
\hline ECPA & Energy Conservation and Production Act \\
\hline ECUT & Energy Conservation and Utilization Technology \\
\hline EEI & Edison Electric Institute \\
\hline EES & Energy Extension Service \\
\hline EPA & Environmental Protection Agency \\
\hline EPRI & Electric Power Research Institute \\
\hline ER & Energy Research \\
\hline ERIP & Energy Related Inventions Program \\
\hline ESCO & Energy service company \\
\hline EUR & Energy Utilization Research \\
\hline FEMP & Federal Energy Management Program \\
\hline FHA & Federal Housing Authority \\
\hline FLC & Federal Laboratory Consortium \\
\hline GNMA & Government National Mortgage Association \\
\hline GPO & Government Printing Office \\
\hline GRI & Gas Research Institute \\
\hline GSA & General Services Administration \\
\hline HBAs & Home Builder Associations \\
\hline HBI & Home Builders Institute \\
\hline HUD & Housing and Urban Development (Department of) \\
\hline IAQ & Indoor air quality \\
\hline ICP & Institutional Conservation Program \\
\hline IEA & International Energy Agency \\
\hline
\end{tabular}




\begin{tabular}{|c|c|}
\hline IUPP & integrated utility planning processes \\
\hline LBL & Lawrence Berkeley Laboratory \\
\hline LCC & life-cycle costing \\
\hline LCUP & Least-Cost Utility Planning \\
\hline LIHEAP & Low-Income Home Energy Assistance Program \\
\hline MIT & Massachusetts Institute of Technology \\
\hline NAHB & National Association of Home Builders \\
\hline NAHRO & National Association of Housing and Redevelopment Officials \\
\hline NARUC & National Association of Regulatory Utility Commissioners \\
\hline NASA & National Aeronautics and Space Adminisiration \\
\hline NASEO & National Association of State Energy Officials \\
\hline NATAS & National Appropriate Technology Assistance Service \\
\hline NCSBCS & National Conference of States on Building Codes and Standards \\
\hline NEESA & National Energy Extension Service Act \\
\hline NESC & National Energy Service Council \\
\hline NIBS & National Institute of Building Sciences \\
\hline NIST & National Institute of Standards and Technology (within DOC) \\
\hline NTIS & National Technical Information Service \\
\hline OBT & Office of Building Technologies \\
\hline OECD & Organization for Economic Cooperation and Development \\
\hline OPA & Office of Public Affairs (within DOE) \\
\hline ORNL & Oak Ridge National Laboratory \\
\hline ORTA & Office of Research and Technical Applications \\
\hline OSLAP & Office of State and Local Assistance Programs \\
\hline OSTI & Office of Scientific and Technical Information (at ORNL) \\
\hline OTC & Office of Technology Commercialization (within NIST) \\
\hline OTFA & Office of Technical and Financial Assistance \\
\hline PHAs & Public Housing Authority \\
\hline PUC & Public Utilities Commission \\
\hline PVE & petroleum violation escrow \\
\hline R\&D & research and development \\
\hline RFP & request for proposals \\
\hline SBIR & Small Business 'Innovation Research \\
\hline SBSE & Society of Building Science Educators \\
\hline SECP & State Energy Conservation Program \\
\hline SEO & state energy office \\
\hline SERI & Solar Energy Research Institute \\
\hline STIP & Solar Technical Information Program \\
\hline TIG & technićal information guide \\
\hline TIS & Technical Inquiry Service \\
\hline VA & Veterans Administration \\
\hline WAP & Weatherization Assistance Program \\
\hline
\end{tabular}




\section{INTRODUCTION}

The U.S. Department of Energy's Office of Building Technologies (OBT) may wish to use existing networks and infrastructures wherever possible to transfer energy-efficiency technologies for buildings. The advantages of relying on already existing networks are numerous. These networks have in place mechanisms for reaching audiences interested in energy-efficiency technologies in buildings. Because staffs in trade and professional organizations and in state and local programs have responsibilities for brokering information for their members or client organizations, they are open to opportunities to improve their perfornance in information transfer. OBT, as an entity with primarily R\&D functions, is, by cooperating with other programs, spared the necessity of developing an extensive technology transfer program of its own, thus "reinventing the wheel." Instead, OBT can maximize its investment in technology transfer by relying extensively on programs and networks already in place. OBT can work carefully with staff in other organizations to support and facilitate their efforts at information transfer and getting energy-efficiency tools and technologies into actual use. Each organization in such arrangements stands to benefit by being better able to meet its goals. Thus, the relationships envisioned are not simply client-contractor ones, but rather ones in which each organization brings resources to bear to meet common goals.

Forging such linkages may, therefore, be a key future DOE approach to-technology transfer. Consequently, representatives of some 22 programs and organizations were contacted, and face-to-face conversations held, to explore what the potential might be for transferring technology by linking with OBT. The informal discussions focused on identifying opportunities for linkage to transfer buildings energy-efficiency technologies and on identifying any problems that might be involved.

The results reflect the perspectives of persons in the programs with which OBT might forge linkages. The problems identified are of two types: (1) the organization's unmet needs for infornation that OBT could provide and (2) possible barriers to forning productive linkages. The opportunities are defined from the standpoint of the other organization, not from the OBT management's point of view.

The briefs that follow were derived from the discussions, the newly published Directory of Energy Efficiency Information Services for the Residential and Commercial Sectors, and other sources provided by respondents. Each brief has been sent to persons contacted for their review and comment one or more times, and each has been revised to reflect the review comments.

The briefs identify the organization and relevant programs; provide the contact person's name and contact information; define the audience(s); mention the relevant funding levels or organizational size, where this was not considered sensitive; describe the programs briefly; and list barriers to and opportunities for linkages with OBT.

The organizations included for review may be classified as

- U.S. Department of Energy (DOE) programs,

- Existing federal information services,

- Other federal programs (non-DOE), and

- Trade and professional organizations.

The organizations were selected for attention on two bases:

(1) OBT management specifically identified certain programs as being of particular interest.

(2) An ad hoc OBT Technology Transfer Advisory Group requested more information about certain programs. 
The list of organizations/programs interviewed is in no sense intended to be exhaustive. Instead, it is a preliminary effort to identify potential, significant near-term opportunities to enhance energy efficiency in buildings through effective technology transfer. Many other organizations are equally worthy of attention and of being included in OBT efforts to transfer technology through existing programs. Since this was a planning effort, it was not possible to include every organization. In the future, however, OBT may expand its efforts to interact with existing networks.

The organizations included in this study are as follows:

\section{DOE Programs:}

Office of Technical and Financial Assistance (OTFA)

Energy Related Inventions Program (ERIP)

State Energy Conservation Program (SECP)/Energy Extension Service (EES)

Institutional Conservation Program (ICP)

Weatherization Assistance Program (WAP)

Federal Energy Management Program (FEMP)

Small Business Innovation Research (SBIR)

\section{Information Services:}

Conservation and Renewable Energy Inquiry and Referral Service (CAREIRS)

National Appropriate Technology Assistance Service (NATAS)

Solar Technical Information Program (STIP)

Federal Laboratory Consortium (FLC)

\section{Other Federal Programs:}

Housing and Urban Development (HUD) Public Housing

Other HUD Programs

National Institute of Standards and Technology (NIST) Office of Research and Technical Applications (ORTA)

NIST Center for Building Technologies (CBT)

\section{Trade and Professional Organizations:}

National Association of Regulatory Utility Commissioners (NARUC)

National Association of State Energy Officials (NASEO)

The U.S. Conference of Mayors

National Association of Home Builders (NAHB)

NAHB Research Center

National Institute of Building Sciences (NIBS)

Building Thermal Envelope Coordinating Council (BTECC) 


\section{SUMMARY}

\section{DOE Programs}

Eight DOE programs were contacted. Five of these fell under the former Office of State and Local Assistance Programs (OSLAP). The other three are the Federal Energy Management Program, the Energy Related Inventions Program, and the Small Business Innovation Research program.

The Office of Technical and Financial Assistance, which replaced OSLAP, administers the five major national grant programs:

1. The State Energy Conservation Program (SECP) provides financial and technical assistance to states to establish and support energy conservation programs at state and local levels.

2. The Energy Extension Service (EES) was designed to provide information on energy conservation to the general public.

3. The Institutional Conservation Program (ICP) originally focused on schools and hospitals and now administers voluntary 50/50 matching grants for energy efficiency projects in institutional buildings.

4. The Weatherization Assistance Program (WAP) provides services and products to assist lowincome households, particularly those of the elderly and the handicapped, to reduce energy consumption and costs.

5. The Energy Related Inventions Program. (ERIP) provides support to inventors for technology and business development in producing and marketing new energy products.

If pending legislation is enacted, the EES would be rolled into the SECP, which would carry forward its functions.

These programs have been supported by Congressional appropriations, by petroleum violation escrow funds, and by state funds. Because the programs are administered by the states, OSLAP found it useful to sponsor an annual All-States Meeting where the cognizant state officials convened to share information and discuss common problems. In addition, OSLAP programs published and distributed newsletters and maintained informal networks as means of communication.

These programs were mandated to disseminate information on energy efficiency, provide technical assistance, evaluate energy program designs, conduct research in support of these activities, and support the actual implementation of energy programs, including the installation of measures in buildings. These programs therefore represent the potential for a critical interface between DOE's R\&D programs in energy efficiency and renewables and the promulgation and use of research results to certain audiences--largely state and local agencies responsible for administering and carrying out the grant programs.

The Federal Energy Management Program (FEMP) develops policy and regulations for energy use in the federal sector. FEMP also prepares annual reports to the President and Congress on federal energy management. Through the national laboratories, FEMP provides technical assistance on energy efficiency to agencies. The program also publishes a quarterly technical bulletin. The $80 \%$ of federal buildings belonging to the Department of Defense yield a $\$ 1.6$ billion annual energy bill. Federal buildings are of particular interest for two reasons: (1) the opportunities for both energy and taxpayer dollar savings are vast, and (2) federal buildings can be used as demonstration projects and examples of energy efficiency accomplishments in commercial buildings for other public- and private-sector organizations. (FEMP is now one of the programs within OBT.) 
The Energy Related Inventions Program (ERIP) and the Small Business Innovation Research Program (SBIR) support the development and commercialization of innovative technologies. Neither program focuses solely on energy efficiency technologies; however, conservation and renewables technologies are supported in each program. Both programs stimulate technological innovation and work with small, entrepreneurial firms. These programs could be a conduit for R\&D results through the interaction of inventors and entrepreneurs with national-laboratory and corporate scientists working on similar or related problems. This type of scientific information exchange could aid in the development of products and processes that result from scientific synergy. OBT could also include new technologies from these programs in its technology transfer efforts.

\section{Federal Information Services}

Four federally supported information services were contacted: the Conservation and Renewable Energy Inquiry and Referral Service (CAREIRS), the National Appropriate Technology Assistance Service (NATAS), the Solar Technical Information Program (STIP), and the Federal Laboratory Consortium (FLC).

The Conservation and Renewable Energy Inquiry and Referral Service used to be known as the National Solar Heating and Cooling Information Center (NSHCIC) and was operated by the Franklin Institute in Philadelphia during the late 1970s and early 1980s. In those days, the program was funded at approximately $\$ 6$ million annually. In recent years, DOE has funded CAREIRS at about $\$ 1$ million annually to provide material to the general public on energy conservation and renewable energy. CAREIRS emphasizes the development of materials appropriate for use by the general public, educators, students, libraries, and professional and trade associations. CAREIRS distributes 147 fact sheets on energy topics. The CAREIRS service has not been evaluated, although the staff logs inquiries and referrals handled. The information provided is generic and responses are not tailored to specific inquiries.

The National Appropriate Technology Assistance Service provides information services and technical assistance in implementating energy efficiency and renewable energy technologies to individuals, state and local energy managers, small businesses, farmers, architects, builders, educational institutions, and others. The responses to inquiries are tailored to meet specific needs. NATAS also develops articles and publications on energy topics, makes referrals, and provides technical assistance on business strategies. The tailored nature of the responses makes this service particularly useful to those interested in developing, marketing, and applying energy efficiency and renewable energy technologies.

The Solar Technical Information Program also provides technical information on renewable energy research and technologies to scientific, industrial, and public-sector audiences. STIP packages current technical information in concise form tailored for the intended audiences. In addition to referrals, STIP provides tailored responses to inquiries. STIP emphasizes the development of technical information products, such as periodicals, publications, exhibits, and reference works on solar energy and energy efficiency R\&D, technologies, and programs. Located at the Solar Energy Research Institute in Colorado, STIP has special expertise in renewable energy technologies and primarily serves the scientific and business community rather than energy end users.

The Federal Laboratory Consortium encompasses the R\&D of the federal laboratory system, and thus is not limited to energy efficiency technologies. It serves the technology transfer needs of trade and professional groups representing small businesses, industry, and state and local governments. FLC's principal purpose is to facilitate technology transfer from federal laboratories to private- and publicsector organizations. It maintains a clearinghouse on scientific topics being pursued at the laboratories; publishes a monthly newsletter; provides training on technology transfer; and hosts conferences, demonstration programs, and other activities. The FLC has no special expertise in energy technologies; 
its strength lies in its ability to access energy researchers wherever they are located in the nation's laboratory system. Such access would be of principal interest to buildings researchers.

\section{Other Federal Programs}

The federal programs beyond DOE that were explored as part of the current effort included programs at the U.S. Department of Housing and Urban Development (especially public housing and six other types of HUD programs) and at the National Institute of Standards and Technology (including the Office of Technology Commercialization and the Center for Building Technology).

HUD Public Housing, working through the more than 3,000 public housing authorities nationwide, administers the public housing program with 11,000 public housing projects and approximately 1.3 million units housing more than 3 million occupants. The HUD program subsidizes an energy bill totaling some $\$ 800$ million annually. Public housing projects use twice as much energy as privatesector housing; the savings potential is $\$ 500$ million a year to put public housing at the same level. An estimated $\$ 1$ billion in energy efficiency improvements is needed in public housing. The opportunity for energy efficiency improvements is vast.

Other HUD programs that offer significant potential for energy efficiency improvements fall under six categories: (1) insurance programs for mortgages and loans, (2) direct loans, (3) subsidized housing, (4) Community Development Block Grants, (5) Rehabilitation Assistance Program, and (6) Govemment National Mortgage Association (GNMA). Together with public housing, these projects significantly affect the nation's housing and the energy used in housing. HUD's energy bill for public and other assisted housing approaches $\$ 1.5$ billion each year. HUD provides approximately $\$ 1.7$ billion annually for capital improvements and major repairs for public housing, and $\$ 2.9$ billion each year for community development, about a third of which is used for property rehabilitation. HUD acquires 86,000 "HUD Homes" each year and sells them as is, with no improvements. Altogether, about 5.4 million housing units are affected by HUD policies and programs. With joint planning and DOE technical assistance activities, the relevant HUD programs could be transformed into vehicles for improving energy efficiency in the nation's housing using cost-effective approaches. These programs could still meet their mandates, and they could do so more efficiently.

The National Institute of Standards and Technology recently reorganized and replaced its Office of Research and Technology Applications with an Office of Technology Commercialization (OTC). This office specializes in technology transfer. The OTC has surveyed the states concerning their use of technology as part of economic development programs. The OTC located 230 organizations spending $\$ 620$ million annually on economic development programs. The OTC is sponsoring a workshop series for states to inform them about federal resources. Among the federal agencies, NIST has a particularly good rapport with industry. Working with NIST to transfer energy-efficient technologies through economic development organizations at the state level, and possibly to link state energy offices with state economic development offices, could be a significant opportunity.

NIST's Center for Building Technology works to increase the usefulness, safety, and economy of buildings through the advancement of building technology. It works on technical bases for improved structural and earthquake design criteria. CBT provides technical bases for selecting cost-effective materials, such as protective coatings, roofing systems, and cement hydration. In addition, CBT provides modeling, measurement, and test methods for using automation in construction, improving the quality of the indoor environment, and improving the performance of building equipment. CBT runs a Building Technology Symposia series, attended mostly by federal agency personnel, that provides presentations on state-of-the-art technologies using one-day formats. Audiences could be expanded to include decision makers affecting building design or other ways in which energy is used. 


\section{Trade and Professional Organizations}

While many relevant trade and professional organizations could have been included here, time and resources limited the current effort to seven organizations: (1) the National Association of Regulatory Utility Commissioners, (2) the National Association of State Energy Officials, (3) the U.S. Conference of Mayors, (4) the National Association of Home Builders, (5) the NAHB Research Center, (6) the National Institute of Building Sciences, and (7) the Building Thermal Envelope Coordinating Council.

The National Association of Regulatory Utility Commissioners is important because of utility integrated resource planning (IRP). IRP includes both supply and demand technologies and fosters cost (not necessarily energy use) reduction, although frequently the two overlap. NARUC membership includes state, federal, and Canadian public utility commissioners responsible for regulating utility companies and the telephone, water, gas, insurance, banking, and taxicab industries. NARUC, a source of information for the commissioners, publishes a weekly newsletter and holds conferences. NARUC committees develop commission policies on an array of topics. The Energy Conservation Committee develops NARUC policy and presents resolutions conceming energy efficiency to the full membership. The NARUC commissioners and staff want to know the latest developments in lighting, windows, and other energy efficiency and renewable energy technologies. They need solid evidence of technology performance and effective energy service delivery programs.

The National Association of State Energy Officials functions to update the states on activities in Washington and to act as a liaison between state and federal officials. NASEO publishes a quarterly newsletter and sponsors two meetings each year. Among the organization's committees are energy emergencies, integrated energy planning, SECP, appliances and building standards, R\&D, and global warming. OSLAP staff were interested in relationships with state officials responsible for administering state and local grant programs, and NASEO is the officials' professional association. One opportunity to improve building energy efficiency through NASEO is to deal with state concerns about improving the energy efficiency of state-owned buildings.

The U.S. Conference of Mayors represents mayors of cities of 30,000 or more population and deals with a broad array of urban issues. The Conference has access to an extensive network of urban decision makers, publishes a semimonthly newspaper, and holds two major meetings each year. The established communications mechanisms could offer opportunities to promulgate energy efficiency information of interest to city administrators.

The National Association of Home Builders represents some 50,000 home builders and 107,000 others in related occupations. Affiliated with NAHB are 800 state and local home builder associations (HBAs). Information flows from NAHB to the HBAs, each of which has its own newsletters, seminars, meetings, and educational programs. NAHB owns the Home Builders Institute, which offers energy courses and seminars. NAHB also maintains a bookstore and publications catalog. NAHB is developing a program involving standards development, builder training and education, certification and quality assurance, research, and promotion and marketing.

The NAHB Research Center is a wholly-owned, not-for-profit subsidiary of the NAHB, with a threefold mission: (1) to conduct applied research on buildings technology, (2) to promote quality standards in building materials and construction, and (3) to help maintain the U.S. building industries' competitive position. The Center has a Research Home Park that tests technologies, documents results in major trade publications, and displays them to the 2,500 builders attending the annual spring meeting. The Center's staff write articles about buildings technologies for a variety of magazines. The Center offers opportunities in research collaboration and in demonstrations of technologies and practices of particular interest to builders. 
The National Institute of Building Sciences is a nongovernment, nonprofit corporation established in response to federal statute. NIBS was conceived as a public/private partnership to resolve technical and regulatory issues facing the nation's housing and building processes. The organization's membership includes representatives from across the building community, including public interest groups, all levels of govemment, consumers, code officials, architects, engineers, builders, developers, product manufacturers, and standards organizations. NIBS efforts relate especially to performancecriteria-based standards and other technical provisions to evaluate building products, systems, and component parts. NIBS also works to facilitate the use of performance criteria in certifying, listing, and labeling programs. Among its activities, NIBS maintains the Construction Criteria Base (CCB), a data base on building specifications, standards, codes, and other technical criteria. CCB information is provided in CD-ROM form to a rapidly growing number of subscribers (currently approaching $1,000)$, many of whom are design professionals. 
DOE PROGRAMS 


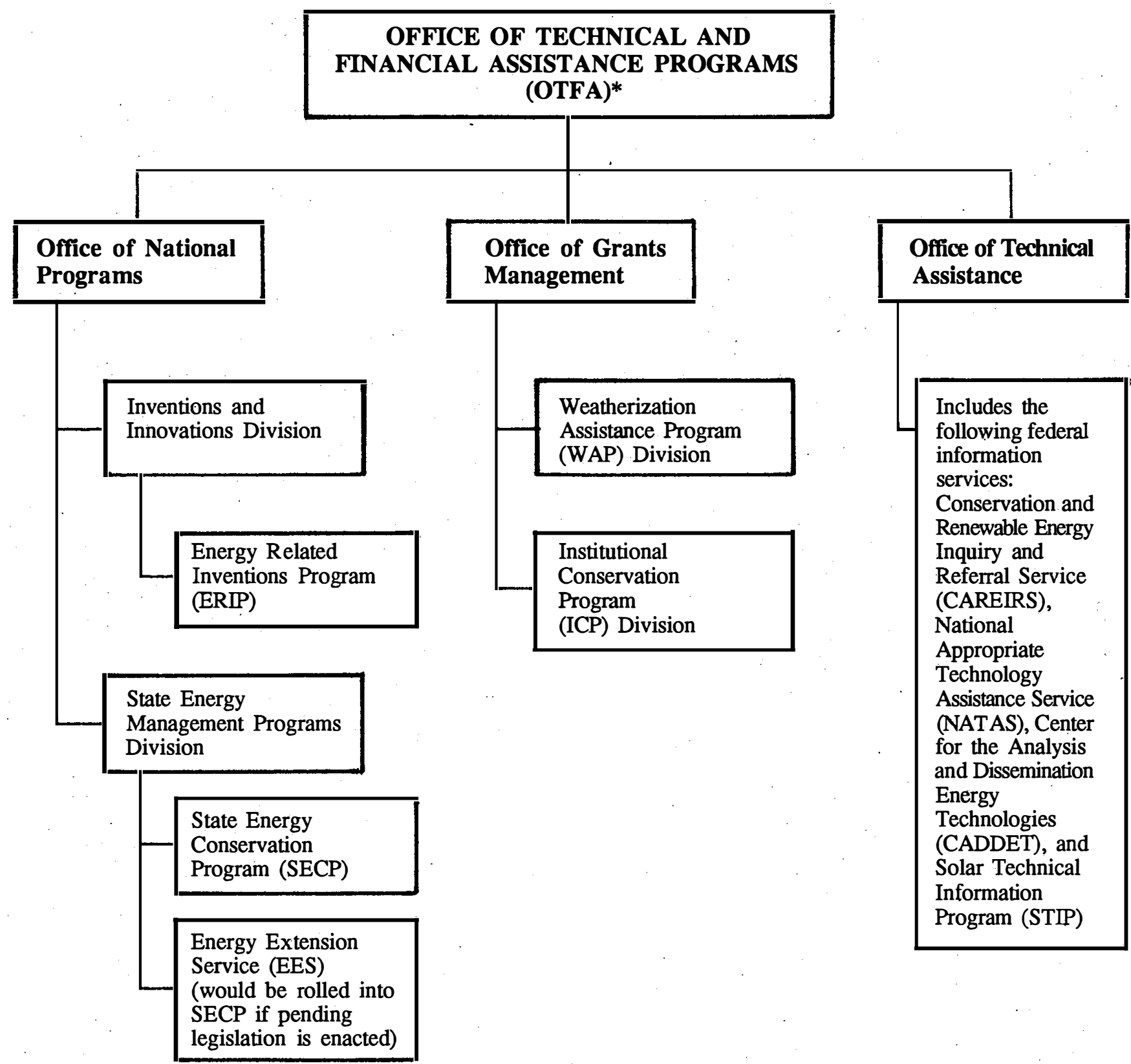

*This chart reflects the CE organization announced April 19, 1990. 


\section{OFFICE OF TECHNICAL AND FINANCIAL ASSISTANCE (OTFA)}

Name of program: Office of Technical and Financial Assistance (OTFA)

\section{Contact person/ organization:}

\section{Audience:}

Funding:

Description:
Mr. Frank Stewart, Deputy Assistant Secretary

Office of Technical and Financial Assistance

U.S. Department of Energy

1000 Independence Ave., SW

Washington, DC 20585

(202) $586-9240$

State and local governments; private and nonprofit organizations

Under the CE reorganization, OTFA funding subsumes all state and local assistance programs (see descriptions of those programs)

OTFA's mission is to encourage the use of renewable energy and energy efficiency by working cooperatively with state and local governments and private and nonprofit organizations. The Office transmits technical and financial assistance from DOE and encourages active participation by the states in planning DOE programs.

Three offices have been created that report to the Deputy Assistant Secretary for Technical and Financial Assistance. These are the Office of National Programs, the Office of Grants Management, and the Office of Technical Assistance. The Office of National Programs includes the Inventions and Innovation Division that administers the Energy Related Inventions Program (ERIP) and the State Energy Management Programs Division that administers the Energy Extension Service (EES) and the State Energy Conservation Program (SECP). The Office of Grants Management includes the Weatherization Assistance Program (WAP) and the Institutional Conservation Program (ICP). The Office of Technical Assistance administers federal information services, including CAREIRS, NATAS, and STIP.

In the past, among other activities, OTFA has sponsored reviews of the utility commercial-energy-conservation program offerings, surveyed state/utility cooperation, assessed the marketing and design of energy programs for the elderly, developed a demand-side management (DSM) primer with EPRI, and cosponsored four national DSM conferences. OTFA staff have arranged for CE staff to present material on renewables to state program personnel at Support Office meetings. They have also participated in the Least-Cost Utility Planning (LCUP) project.

1. Harry Lane thought that "technology push" is perceived at DOE as more important in commercializing energy technologies than "demand-side pull." DOE tends to consider its job done when companies can adopt technologies, produce products, and put them in their product lines. However, companies still have to educate installers and consumers (in other words, develop a market for the product), and so on. The respective roles of government and the private sector are still being defined. In his view, technology 
Opportunities:

transfer occurs when information goes from $\mathrm{A}$ to $\mathrm{B}$, and $\mathrm{B}$ acts on the information, and the failure to focus on demand pull sometimes limits the amount of action resulting from technology transfer.

2. The technical expertise available at the national laboratories is not necessarily accessible by state energy office staffs. Where resources flow from the SEOs to the laboratories, the relationships work well. [Existing examples are Lawrence Berkeley Laboratory (LBL)/Michigan and LBL/ Wisconsin.]

1. OTFA has the mission to be a technology-transfer arm for all of CE. OTFA staff members are comfortable and experienced in the technology transfer arena with energy service delivery organizations (especially utilities and SEOs) and are eager to perform in this mission area. . They have existing contacts and mailing lists.

2. State energy offices could play a valuable role in support of LCUP activities at the state level. Some scattered activity has occurred, but OTFA staff members could do more to encourage SEOs to see themselves as players and equip them to participate in Public Utility Commission (PUC) deliberations. For example, working with other DOE staff, OTFA could set up a series of demonstrations to show SEOs how best to play a role in LCUP in the states. This could be done by selected demonstration projects, case studies, or providing backup technical assistance to SEO staffs that want to work with PUCs. Also, PUCs would have to be willing to have SEO people involved, and state procedures would have to be open to SEO participation with or testimony before the PUC.

3. OTFA staff members can act as advisers to end-use-sector researchers, including building researchers, in terms of content and presentation of technical material for general audiences. OTFA is cognizant of the translation problem between researchers and user audiences and understands how to bridge the gap and tailor information specifically for those user audiences.

4. OTFA can work with energy intermediaries to encourage them to market energy technologies.

5. OTFA can help in identifying the audiences for technologies at project inception.

6. Support Offices in Boston and Chicago have recently held technologytransfer workshops with their states. They provided sessions on all the national laboratories and their capabilities. The audiences for these workshops were the economic development, energy, and environmental offices in those states.

7. A bimodal strategy can be useful. It is helpful for information users to receive the same information from two different credible sources. Both OTFA and end-use sectors have technology transfer activities that will be coordinated so that they are mutually supportive. OTFA and end-use sector staff members in buildings, utilities, transportation, and industrial processes will work together to achieve effective technology transfer. 


\title{
ENERGY RELATED INVENTIONS PROGRAM (ERIP)
}

\author{
Name of program: Energy Related Inventions Program (ERIP) \\ Contact person/ \\ Ray Bames \\ organization: \\ Inventions and Innovation Division \\ Office of Technical and Financial Assistance \\ U.S. Department of Energy \\ 1000 Independence Ave., SW \\ Washington, DC 20585
}

(202) $586-1692$

[Note: Program is operated jointly with the National Institute of Standards and Technology (NIST)]

Audience: $\quad$ Inventors

Funding: $\quad \$ 5$ million/year for all types of inventions

Description: $\quad$ Congress established the program in 1974 to foster U.S. inventors' creative ideas. NIST performs technical evaluations and feasibility studies; DOE awards grants, holds commercialization workshops, and performs periodic program evaluations.

DOE funds NIST to review inventions submitted to the program and to recommend to DOE those that are identified as promising. DOE then funds the selected inventors for between $\$ 50,000$ and $\$ 95,000$ to take the next step in the development of the invention. NIST only recommends $3 \%-4 \%$ of the 1,000 applications that come in yearly. NIST evaluates the inventions for technical and commercial feasibility but does not perform a full market study. NIST considers whether a need exists and the invention is significant enough to meet that need. About $30 \%$ of the inventions NIST has recommended and DOE has funded have succeeded; this is considered a high rate given the rate of success for venture capital investment success. NIST also provides technical information to innovators in the ERIP program and keeps their files open so that the inventors can come back and ask for more technical assistance.

The DOE ERIP staff maintains caseloads of inventors with whom they work. ERIP staff informs inventors about the state-of-the-art of the technology area in which they are working. Projects run from initial concept to those ready for commercialization. Some inventors are directed to SBIR, if they qualify under that program's restrictions.

Problems: $\quad$ The main barrier to an OBT-ERIP linkage seems to be that ERIP works with inventors in small organizations, whereas OBT works primarily with national laboratory researchers. Thus, the two programs are working to develop technologies through different types of organizations. 
Opportunities:

1. The former BCS was involved in shared funding in a small number of ERIP projects; this activity could continue under OBT auspices.

2. The former BCS provided ERIP with technical expertise in an advisory capacity. This activity also could continue with OBT. These two activities indirectly help technology transfer because they contribute to the development of energy-efficiency technologies for which commercialization is assisted through the ERIP program.

3. ERIP could help OBT-funded projects in the area of commercialization. 


\title{
STATE ENERGY CONSERVATION PROGRAM (SECP)
}

\author{
Name of program: State Energy Conservation Program (SECP) \\ Energy Extension Service (EES) \\ Contact person/ \\ organization: \\ Jerry Duane \\ State Energy Management Programs Division \\ Office of Technical and Financial Assistance \\ U.S. Department of Energy \\ 1000 Independence Ave., SW \\ Washington, DC 20585
}

Audience:

Funding:

Description:
(202) $586-2344$

State energy offices (SEOs) and their contacts with local organizations

SECP: $\$ 9.6$ million nationwide in FY 1989

EES: \$3.9 million nationwide in FY 1989

The SECP provides financial and technical assistance to states to establish and support energy conservation programs at state and local levels. Through SECP, states promote energy efficiency and reduce energy demand. SECP requires them to match $20 \%$ of federal funds received. SECP's enabling legislation requires that states develop and implement programs in five areas: lighting efficiency standards in public buildings, carpool programs, energy efficiency in procurement, thermal efficiency standards, and right-turn-on-red.

States also develop other activities linked to an overall state energy conservation goal. Emphasizing energy education and information transfer, conservation retrofits and public/private partnerships, states have established programs in agriculture, industry, transportation, education, utilities, buildings, government, and small business. States are permitted to use up to one-third of their SECP funds to purchase and install retrofits under certain conditions.

EES, which has been run through the state energy offices, was intended to provide information on energy conservation to the general public. EES provides tailored information and specialized technical assistance about energy conservation and the use of renewables. Through this program, the states receive financial support to assist individuals, small business owners, and local govemment officials in managing their energy usage. EES funds also require a $20 \%$ match of state. funds.

Since the earliest days, program activities have evolved and broadened, but with nationwide funding at $\$ 3.9$ million, some state allocations are so small that the program can fund only one staff person.

Currently, Congress is considering consolidating EES and SECP. It may be more efficient to combine the two programs. New legislation has been proposed repealing the National Energy Extension Service Act (NEESA) and mandating its functions under SECP. The SECP and EES funding would be merged. 
Problems:

Opportunities:

1. Former OSLAP and BCS staff members have had their own mandates and tended to concentrate on their own agendas. Until the CE reorganization, no specific responsibility for coordinating outreach efforts between OSLAP and BCS had been assigned. With the CE reorganization, greater coordination may be facilitated between the offices responsible for R\&D and those responsible for outreach.

2. Some SEOs and national laboratories have forged relationships with each other, while others have not.

1. A technology transfer arm within OTFA has been established in the Office of Technical Assistance. OTFA staff could be assigned to liaise with OBT. Information flow between OTFA and OBT could become routine.

2. An OBT staff member could be assigned to liaise with OTFA's technical assistance staff, or each OBT division could assign such a liaison responsibility. Interaction could be facilitated if OTFA had one liaison point so that OBT staff would not have to interact with each different OTFA program separately to transfer technology.

3. The SEO staff members understand building technologies and they have expertise in energy matters; some of them have advanced in-house capabilities. Some of the more sophisticated SEOs are reaching energy intermediaries, such as builders. Opportunities may exist for expanding the role of the national laboratories in supporting the SEOs. 


\section{INSTITUTIONAL CONSERVATION PROGRAM (ICP)}

Name of program: Institutional Conservation Program (ICP)

Contact person/ organization:

Audience:

Funding:

Description:

Problems:

\author{
William Minning \\ Patricia Rose \\ Mail Stop CE-231 \\ U.S. Department of Energy \\ 1000 Independence Ave., SW \\ Washington, DC 20585
}

(202) 586-9645

State energy offices (SEOs); administrators of schools and hospitals and their professional associations

FY 1989: \$25 million

The ICP was instituted under the National Energy Conservation Policy Act of 1978 (NECPA) (P.L. 95-619). The act provides for the federal administration of a voluntary 50/50 matching-grants program for energy audits and the purchase and installation of energy-efficiency equipment in institutional buildings.

Two major program activities have been the matching grants program for schools and hospitals and developmental projects. Most of the latter have been completed. The Schools and Hospitals program continues as the core ICP effort. More than $\$ 775$ million have been distributed to institutions to help finance conservation improvements.

Now-completed "Tier 1" projects began in 1986 to provide seed grants to SEOs to conduct innovative energy conservation projects for schools and hospitals. They used financing, information transfer, or other mechanisms and targeted either schools or hospitals. Utah, Tennessee, South Carolina, Vermont, Colorado, Ohio, Pennsylvania, New Mexico, Nebraska, Wisconsin, New York, and Oklahoma received Tier 1 project grants.

1. The schools and hospitals administrations do not perceive energy costs as a significant enough portion of their operating budget to warrant energy efficiency investments. Fuel costs are only 3\% of operating budgets; with $\mathrm{O} / \mathrm{M}$ costs, energy costs increase to $8.5 \%$. A significant issue in education currently is the fact that deferred maintenance is resulting in decayed physical plants.

2. Administrative issues preclude staff members from being innovative; also, staff members have no incentive to initiate change and may even be discouraged from doing so, even when their actions result in significant budgetary savings.

3. Functions for the different organizations of DOE are under review, and staff members will focus on reorganization issues until these are resolved. 
Opportunities: $\quad$ [Note: OBT and ICP already have some existing linkages that could aid in technology transfer:

- ICP has already worked with the former BCS program in LCUP projects at the DOE staff level.

- The International Energy Agency (IEA) has a special committee, Hospital Annex, that has developed a guide for hospital administrators. OBT is already collaborating on this effort.

- OBT (Emie Freeman) funded a book on retrofitting commercial buildings.]

1. Presenters at professional meetings are needed, both DOE program managers and peers who "did it." The Association of School Business Officials, the Association of Physical Plant Administrators, and other groups are important audiences to target.

2. Magazine articles and trade journals are important vehicles for reaching these audiences.

3. If OBT and ICP could share the trade and professional associations that each is working with, efforts could be coordinated to greater effect overall.

4. ICP publishes Facts and Features, a quarterly newsletter that goes to an audience of about 1,000 that includes SEOs, DOE field offices, and association members.

6. ICP maintains publications on energy efficiency at DOE headquarters and responds to inquiries. If OBT has any publications relevant to the commercial sector, ICP could maintain and disseminate a supply.

7. OBT could hold program reviews for ICP and other OTFA staff on the R\&D program and technology-transfer efforts.

8. The annual All-States Meeting represents a significant opportunity to reach SEO staff people; attendance has reached 500, and other organizations are also represented. Emerging technologies would be of interest to this audience, along with information on technologies and products already available.

9. Perhaps the Office of Conservation and Renewable Energy (CE) could have a centralized group to coordinate focus on the technologies $C E$ is developing for end users through a facilitating role. 


\title{
WEATHERIZATION ASSISTANCE PROGRAM (WAP)
}

\author{
Name of program: Weatherization Assistance Program (WAP) \\ Contact person/ \\ organization: \\ Mary E. Fowler \\ Weatherization Assistance Program \\ Office of Technical and Financial Assistance \\ U.S. Department of Energy \\ Forrestal Building, CE-232, 5G-023 \\ 1000 Independence Avenue, S.W. \\ Washington, DC 20585
}

Audience:

Funding:

Description:

Problems:
(202) 586-2204

WAP provides services and products that assist low-income households, particularly those of the elderly and the handicapped, in reducing energy consumption and costs. The program targets single-family and multifamily dwellings, as well as mobile homes, owned or occupied by low-income persons. Through September 1988, over 4 million homes (of an estimated 22 million eligible) have been weatherized with DOE-appropriated, Low-Income Home Energy Assistance Program (LIHEAP), and petroleum violation escrow (PVE) funds.

FY 1989 appropriations: $\$ 161.3$ million. From FY 1977 through FY 1989, WAP funding from appropriated PVE and LIHEAP funds amounted to about $\$ 4$ billion.

The WAP was established by the Energy Conservation and Production Act (ECPA) of 1976 (P.L. 94-385). It is a formula grant program: grantees (the 50 states, the District of Columbia, and 10 Indian tribes) develop plans to meet their particular needs and circumstances which, after review and approval by DOE, are funded for implementation. Funds are allocated on the basis of a formula derived from the WAP statute. The grantees, in tum, select and fund about 1,200 subgrantee organizations (principally, community action agencies) that provide weatherization services to low-income clients. The program is administered through six DOE operations offices and 10 field offices, which review grant applications and state plans, award grants, and monitor operations.

DOE provides technical assistance to the state and local WAP levels, assisting, for example, with health and safety regulations compliance, environmental issues, and determining the most cost-effective weatherization measures for different housing types. Increasingly, the technical assistance provided is in response to needs identified by state and local WAP implementers. Recent projects of this type include assessing the most cost-effective measures for mobile homes and developing an audit for hot, humid climates.

1. DOE/WAP maintains a list of approved measures to which new ones may be added after DOE review of their energy-efficiency performance. From the list, states select the highest priority measures for a dwelling based on relative cost effectiveness for the particular application and the legislated $\$ 1,600$ average expenditure requirement. States may assess the costs of 
Opportunities:

training crew members to install a measure in the context of the total cost to the state program. DOE/WAP or states might not use a new, higher order technology if the installed cost (including training if necessary) is expensive.

2. Full adoption throughout the WAP system of new techniques or technology with national applicability can take a long time--possibly five years or more--depending on the cost, technical complexity, training requirements, and the experience of early WAP adopters with the product.

1. WAP should be advised of the technologies and other findings that OBT produces to see what could be used in the WAP, even though full adoption throughout the WAP system can take several years.

2. Joint OBT-WAP projects can continue to focus on discrete technical problems identified by the WAP system. For example, federally supported laboratory research is helping to define the most cost-effective mobile home retrofits for cold climates (SERI) and to develop an audit for hot, humid climates (ORNL). OBT is a contributor to both projects. WAP cannot support full-scale R\&D but can fund some specific technical work on discrete problems identified by WAP program implementers.

3. At times, technical needs are identified within the WAP infrastructure that WAP itself cannot address and would like to refer to OBT for research. For example, a question has arisen as to whether radiant barriers should be used as a weatherization measure. WAP will rely on OBT work to answer this question.

4. Information ransfer on the mobile home work completed to date is being accomplished through the WAP annual conference, regional meetings, and articles in Home Energy and The Energy Exchange. Also, sessions have been developed to train trainers from the states in the latest results.

5. Individual state or local WAPs might be interested in serving as "test beds" for demonstrating emerging technologies from the end-use sectors, including buildings. 


\section{FEDERAL ENERGY MANAGEMENT PROGRAM (FEMP)}

Name of program: Federal Energy Management Program (FEMP)

Contact person/

Richard Brancato, Director, or Tina Van Sickle

organization:

Office of FEMP

Office of Building Technologies

U.S. Department of Energy

1000 Independence Ave., SW

Washington, DC 20585

(202) $586-5772$

Audience:

Federal government agencies, especially facilities designers, procurement officers, and facilities managers

Funding:

$\$ 1.2$ million in FY 1990, DOE appropriation; other federal agencies cost-share projects

Description:

FEMP develops policy and regulations for energy use in the federal sector. FEMP also prepares annual reports to the President and Congress on federal energy management.

Through the national laboratories, FEMP provides technical assistance to agencies on energy conservation improvements in federal buildings, energy assessment and management techniques, and energy awareness. FEMP distributes information, publications, and software on life-cycle costing (LCC) and A Simplified Energy Analysis Method (ASEAM).

FEMP publishes a quarterly technical bulletin, FEMP Update, to promote technology transfer and report on energy management and shared energy savings initiatives.

Problems:

1. Although some energy experts have viewed the federal govemment role as bulk purchasing of energy efficiency and renewable technologies to promote their commercial use, there are limitations to this approach. Agency management is disaggregated such that purchasing/procurement departments cannot buy energy equipment to help the commercialization process for technologies. Each federal building is different; to acquire 10,000 heat pumps, for example, would not make sense.

2. Although LCC regulations govern major retrofit decisions, certain equipment can be omitted from these decision processes. Regulations on LCC might need improvement or stricter interpretation, such that any time an agency purchases equipment or structure, it would have to lifecycle cost the decision (similar to an LCUP approach). This would create a market to which the private sector could respond.

3. $R \& D$ efforts conducted by cognizant conservation offices to be transferred to other agencies should be conducted in a way that those agencies can use them. One way to help ensure this is to involve federal users in their development. 
Opportunities:

1. The FEMP director described opportunities in the federal government to deploy the expertise available at the national laboratories to help the energy infrastructure do two major things:

- Place advanced technologies in the early stages of commercialization into buildings owned by federal agencies.

- The Federal Energy Management Improvement Act (P.L. 100-615), enacted November 5, 1988, requires agencies to implement procedures to enter into shared energy savings contracts and permits agencies to use cost savings from these contracts to undertake additional energy conservation measures. One opportunity could be to use the laboratories to make/design/plan LCC-effective energy improvements. FEMP is working out mechanisms to do this.

2. Upper management has the opportunity to call for interactions among the different DOE programs to enhance conservation management and integration of activities. This would provide closer integration between FEMP and its federal government customers to help the transfer of OBT technologies.

3. FEMP could join with the General Services Administration (GSA) to offer training in energy conservation for federal facilities managers. GSA maintains training centers throughout the country and trains federal officials in all topics for which the federal government offers training. OBT could give input to GSA training courses on advanced technologies. Currently, for example, GSA is offering training in shared energy savings contracting. 


\section{SMALL BUSINESS INNOVATION RESEARCH (SBIR)}

Name of program: Small Business Innovation Research (SBIR)

Contact person/

Dr. Sam Barish

organization:

SBIR Program Manager

Code ER-16

U.S. Department of Energy

1000 Independence Ave., SW

Washington, DC 20545

Spokesperson: Mrs. Gerry Washington

(301) 353-5867

(Information provided by Mr. Ron Toms and Dr. Sam Barish)

Audience:

Funding:

Description:
Small businesses developing high-technology innovations

\section{$\$ 2.5$ million/year' from CE}

$1.25 \%$ of DOE's extramural research budget goes to SBIR, except for Defense programs; the total for DOE is more than $\$ 30$ million annually

SBIR's objectives are to stimulate technological innovation; use small business to meet federal R\&D needs; increase private sector commercialization of innovations derived from federal R\&D; and foster and encourage participation by minority and disadvantaged persons in technological innovation.

Eleven agencies with an extramural R\&D budget of more than $\$ 100$ million were required to establish an SBIR program using a set-aside of a stated percentage of that budget. The percentage grew from an initial $0.2 \%$ in 1983 to $1.25 \%$ in FY 1986 through 1993.

In FY 1988, DOE received and reviewed 1,214 proposals; in FY 1989 1,543 were reviewed; and 1,171 will be reviewed in FY 1990 . About 23,000 solicitations are mailed out each year.

Funding takes small businesses far enough along to develop products and processes, but not necessarily far enough to manufacture the products. By definition, the program does not deal with existing technologies, but with unproven concepts. Entrepreneurs can get a grant only if they present an innovative concept. Grants come in two phases: (1) $\$ 50,000$ to show the feasibility of the concept; (2) $\$ 500,000$ to do the principal R\&D and, in some cases, to bring the concept to the commercialization stage. The program deals with all of DOE except Defense programs. As examples of state support, New Jersey and New York are offering bridge loans to get products from the innovation stage to manufacture and marketing.

Each year about 30 topics are allocated among the technical areas in DOE in proportion to their contributions to the SBIR budget. The funds are placed in a common pool, and proposals are selected competitively for award on scientific and technical merit. 
Problems:

For the FY 1990 solicitation, 30 topics were defined. For example, fossil energy has five topics and nuclear energy has four. Conservation and renewables have, together, four topics in the current solicitation (up from three last year). These are (1) consumer load management technologies, (2) instrumentation and techniques for nonelectric applications of concentrated solar energy, (3) photovoltaics research, and (4) innovative polymer materials and composites.

SBIR will only accept proposals that respond to one of the technical topics. The decision about the topics for conservation and renewables is made by the Office of the Assistant Secretary for Conservation and Renewable Energy. CE funding is calculated in the Budget Office and provided to SBIR in one lump sum.

Once awards are made, the awardee is assigned to a DOE technical program manager, who provides overall direction and guidance.

The legislation establishing SBIR (P.L. 97-219) was ambiguous on one point. Technology was supposed to be transferred. New technology is being created and transferred under program auspices, yet the entrepreneurs are not being supported to transfer other DOE technology to the extent that they could.

Opportunities: $\quad$ A mechanism could be developed to push knowledge in the direction of the SBIR awardees, such as bringing awardees into meetings or sending them program overviews involving minimal reading. (They have little time to read.) If they could absorb other ideas, their own work would be strengthened, and they could develop useful collaborations for product development and for marketing their own and related products. 
FEDERAL INFORMATION SERVICES 


\title{
CONSERVATION AND RENEWABLE ENERGY INQUIRY AND REFERRAL SERVICE (CAREIRS)
}

\author{
Name of program: Conservation and Renewable Energy Inquiry and Referral Service (CAREIRS) \\ Contact person/ \\ organization: \\ Ms. Elaine Guthrie, DOE Program Manager \\ Office of Technical Assistance \\ Office of Technical and Financial Assistance \\ U.S. Department of Energy \\ 1000 Independence Ave., SW \\ Washington, DC 20585 \\ Contractor: \\ Mr. Lawrence J. Hughes \\ Advanced Sciences, Inc. (ASI) \\ 2000 North 15th Street, Suite 407 \\ Arlington, VA 22201
}

(703) $243-4900$

\begin{abstract}
Audience: $\quad$ General public
Funding:

$\$ 940,000$ annually, with the current contract expiring on June 30,1991 ; funded by Renewable Energy; DOE provides all CAREIRS mailings, with an estimated value of $\$ 25,000 /$ year
\end{abstract}

Description:

CAREIRS responds to general public inquiries for conservation and renewable energy-related information. CAREIRS also provides comprehensive referral service to NATAS, OSTI, NEIC, and SERI. In the latest one-year period for which there were statistics, CAREIRS handled 55,000 inquiries (a 26\% increase over the previous year). Letters accounted for $57 \%$ and phone calls for $43 \%$ of inquiries. About 350 referrals a month were made to other organizations such as NATAS, OSTI, and STIP. About one-half to three-quarters of the inquiries that CAREIRS handles are on conservation.

CAREIRS emphasizes the development of materials appropriate for use by the general public, educators, students, libraries, and professional and trade associations. CAREIRS produces no brand or company-name information, but it references books and trade associations that do. CAREIRS has 147 factsheets in its repertoire, of which 62 were developed by CAREIRS.

The way CAREIRS decides what to propose in its publications development plan is by (1) logging requests for materials it does not have, (2) scanning the trade press for cutting-edge technologies, and (3) performing special-response research on issues.

Problems:

1. If CAREIRS were advertised, its use would increase. As it stands, CAREIRS is listed in telephone directories in some locales, and in the 800 \# directory. (Occasionally, CAREIRS receives a call asking how to become a secretary or something similar regarding career development. However, a name change would be expensive, involving changes to the printing of all CAREIRS publications.) 
DOE's Office of Public Affairs chose to advertise CAREIRS in October 1989 as part of Energy Awareness Week. The ads emphasized energy conservation.

2. Congress has decided to reduce FY 1990 funding for CAREIRS. OTFA is currently requesting funding support for CAREIRS to avoid possible contractor staff cuts.

3. Neither CAREIRS nor an independent contractor has been funded to conduct an evaluation of CAREIRS' effectiveness. CAREIRS does log its inquiries and referrals. (For a program that used to be funded at $\$ 6$ million annually and is currently funded at about a million dollars a year, federal investment in evaluation seems warranted.)

Opportunities:

1. If OBT considers the energy end user to be one of its audiences or if OBT thinks providing consumer information to distributors and other product manufacturers, energy intermediaries, and energy service delivery organizations is one of its roles, then it could consider a more active role with CAREIRS. In coordination with OTFA, OBT could leverage the resource it represents with a relatively modest amount of funding.

2. OBT could earmark funding to CAREIRS (or to another independent organization) for an evaluation study of the usefulness and effectiveness of the CAREIRS approach in promoting energy conservation and the use of renewables.

3. OBT also could earmark funding for advertising of the CAREIRS service to increase its use. However, DOE's Office of Public Affairs and others would have to approve this, and OTFA would have to assess the impact on CAREIRS' capacity and funding.

4. OBT could analyze any potential overlap between CAREIRS' and SumnerRider's work with "information intermediaries" (e.g., the trade press, the regular press, etc.) and structure coordinated efforts.

5. For a modest investment of staff time, OBT could review the CAREIRS publications development plan and could recommend factsheet, paragraph, and other information product topics that should be developed. Also, OBT staff could review conservation-related factsheets.

6. For a somewhat greater investment of staff time, OBT could prepare camera-ready factsheets, such as the one OBT is producing on radiant barriers, for reproduction and distribution by CAREIRS.

7. If OBT provided resources for quantities of publications, such as technical information guides (TIGs), CAREIRS could disseminate them. (For example, at least one of the SERI-produced TIGs was aimed at "anyone interested in energy conservation.") 


\section{NATIONAL APPROPRIATE TECHNOLOGY ASSISTANCE SERVICE (NATAS)}

Name of program: National Appropriate Technology Assistance Service (NATAS)

\section{Contact person/ organization:}

\section{Contractor:}

Audience:

Funding:

Description:

\author{
Anita Dean DeVine, DOE Program Manager \\ Office of Technical Assistance \\ Office of Technical and Financial Assistance \\ U.S. Department of Energy \\ 1000 Independence Ave., SW \\ Washington, DC 20585
}

(202) $586-1265$

Jeff Birkby

P.O. Box 2525

Butte, MT 59702

$1-800-428-2525$

Individuals, homeowners, state/local energy managers, small businesses, energy innovators, farmers, architects, builders, educational institutions, and nonprofit organizations

\section{$\$ 1.4$ million in FY 1990}

NATAS provides information services and technical assistance with the implementation of energy efficiency and renewable energy technologies. NATAS responds to inquiries in several ways including: (1) immediate response to requests for technical information, (2) copies of relevant articles, (3) bibliographic listings, (4) referrals to other resources, and (5) detailed answers to specific technical questions.

About $29 \%$ of NATAS's queries concem buildings, and another $25 \%$ concern HVAC equipment, totaling more than one-half (54\%) of NATAS queries on OBT-related energy conservation topics.

NATAS has developed four publications to respond to frequently asked questions: Combustion Appliances in Energy Efficient Homes, Combustion Heating Systems, Energy Efficient Windows, and Insulation. NATAS also maintains a collection of documents from a wide range of sources including magazine articles, product lists, and publications of state and federal governments. These documents are distributed to users as appropriate.

NATAS applies its business expertise to energy projects and small businesses. For example, NATAS will map marketing strategies for energy-related inventions. It will assess a weatherization company's business plan. It answers questions on innovative financing or suggests specific financing options for hospitals, municipalities, and others.

Among other NATAS services are providing brochures about its services for distribution by other organizations or directly distributing these brochures using an organization's mailing lists. 
NATAS also develops articles on conservation and renewable topics for inclusion in newsletters, mailings, and magazines.

Problems:

1. NATAS has a need for the latest information from OBT on saving energy in commercial buildings, currently a hot topic.

2. In general, NATAS needs to know when technologies and practices are ready to go on the market; e.g., they are tested, and they are known to perform. They need to know the cutting edge technologically.

3. NATAS staff members have contacts with the energy research community; however, DOE program management would like a means of staying abreast of what DOE sees as the most promising buildings energy-efficiency technologies in the pipeline.

Opportunities:

1. NATAS staff members publicize their program by looking for subjects to write articles on, and placing them in such magazines such as Popular Mechanics and Practical Homeowner. If a new or nearly new technology is being introduced, briefing the NATAS staff would be advantageous. NATAS has writers and editors. The DOE program manager would be willing to be a broker in this process.

2. DOE has funded an evaluation of NATAS by Northwestern University, through ORNL. Although estimating energy savings from a program like NATAS was difficult, the overall findings were that users liked the service. NATAS logs its contacts and sends out a form with its responses. NATAS gets back $35 \%$ of the forms and uses them to maintain quality control. No funding is currently available for evaluation. 


\title{
SOLAR TECHNICAL INFORMATION PROGRAM
}

\author{
Name of program: Solar Technical Infornation Program (STIP) \\ Contact person/ \\ organization: \\ Paul Notari \\ Solar Energy Research Institute (SERI) \\ 1617. Cole Boulevard \\ Golden, CO 80401
}

(303) $231-1317$

\begin{abstract}
Audience:
Scientific, industrial, federal, local, and state government entities

Funding:

Approximately $\$ 1.3$ million annually from the forner Office of Renewable Energy; neither the former Office of Conservation nor the former BCS funded STIP; however, Conservation and BCS had been funding SERI at approximately $\$ 200,000 /$ year to. produce publications
\end{abstract}

Description:

Problems:

STIP's purpose is to provide technical infornation, related to renewable energy research and technologies sponsored by DOE, to scientific, industrial, and publicsector audiences. STIP emphasizes packaging accurate, current technical information in concise form tailored for the intended audiences.

STIP fulfills two major functions:

1. Developing technical information products (periodicals, publications, exhibits, and reference works) on solar energy R\&D and on energy conservation technologies and programs. The majority of STIP's funding-about $\$ 1.1$ million--is used for this function.

2. Operating the Technical Inquiry Service (TIS), an inquiry response service related to solar and conservation research funded by DOE. TIS serves the scientific, industrial, business, and public sector communities, providing definitive responses to technical questions. In addition, TIS refers general public and nontechnical inquiries to NATAS, CAREIRS, and SEOs. TIS responds to about 260 inquiries each month and handles about 175 of these itself, referring the balance to other services. Currently, approximately $15 \%$ of inquiries handled directly by TIS deal with conservation topics. About $12 \%$ of STIP funding, or $\$ 160,000$ annually, supports TIS activities.

Where do technical questions on conservation go? TIS responds to about 30 technical requests on conservation topics each month. Most general public and nontechnical inquiries are referred to CAREIRS or NATAS. SERI has no hotline funding and has not widely advertised its services.

Opportunities: 1. Questions dealing with renewable energy and those associated with conservation frequently overlap. Often, the appropriate response to a question on applications of renewable energy is to recommend a conservation strategy. Thus, TIS already is serving "conservation audiences" to some degree. With modest additional support, TIS could more widely announce its services and expand the scope of topics covered to include a larger spectrum of conservation subjects, continuing to focus on technical questions and assistance beyond that provided by CAREIRS and NATAS. 
2. STIP, except for the TIS activity, is primarily responsible for the preparation of technical publications and research summaries. OBT already uses some of these capabilities and it could expand this use. 
FEDERAL LABORATORY CONSORTIUM (FLC)

Name of program: Federal Laboratory Consortium (FLC) for Technology Transfer

Contact person/ organization:

Audience:

Funding:

Description:

Problems:

Opportunities:
Mr. Del M. DeLabarre

FLC Administrator

Federal Laboratory Consortium

224 West Washington

P. O. Box 545

Sequim, WA 98382-0545

(206) 683-1828

FLC audiences are primarily the private sector, state and local govemments, universities, and member laboratories and agencies. The FLC also supports the technology transfer needs of multiplier groups representing small businesses, industry, and state and local governments.

FLC provides direct services to its $500+$ member R\&D laboratories and centers representing 14 agencies, particularly the technology transfer professionals at those laboratories. DOE and DOD have major member representation.

Approximately $\$ 1.3$ million/year from its member agencies

FLC's principal purpose is to facilitate technology transfer from federal laboratories to industry, state and local governments, and other organizations through a coordinated program for member organizations and their potential collaborators.

FLC provides a variety of services to the laboratories, including training on technology transfer, technology transfer conferences with industry, demonstration programs, exhibits, and so on. Member laboratory representatives have the opportunity to be linked via an electronic mail (E-Mail) system.

FLC's main information service is formal networking--the linking of users and federal laboratory staffs. FLC maintains a Clearinghouse and an intemal resource directory/database that lists laboratories by their technological and scientific expertise and resources. Through the Clearinghouse, a technical inquiry can be disseminated to all of those laboratories having specific expertise in the subject, via E-mail or regular mail. Or, an inquirer might receive a list of all those laboratories along with a contact [generally, the Office of Research and Technology Application (ORTA)] for each one.

FLC News is the organization's monthly newsletter. Other publications are released through NTIS. Selected special publications, such as Putting Technology to Work, are issued periodically.

No particular barriers to stronger ties between BCS and the FLC were identified. A more "proactive" FLC role with regard to the BCS program would require expenditure of resources.

1. OBT could take advantage of this network and referral service by ensuring that all of the laboratories participating in the OBT R\&D effort are properly represented in the FLC Clearinghouse database and in FLC publications. 
2. OBT could advertise the availability of this resource to its program managers and principal investigators.

3. OBT could ensure that its technology-transfer program is highlighted occasionally at the semiannual FLC meetings by presenting speakers and perhaps other materials.

4. OBT could mention the FLC network and Clearinghouse in appropriate OBT publications as a technical assistance resource on energy efficiency technologies for buildings.

These opportunities are low in cost, yet they link OBT into an existing technology-transfer network that showcases the capabilities of the national laboratories. 
OTHER

FEDERAL PROGRAMS 


\title{
HUD PUBLIC HOUSING
}

\author{
Name of program: HUD Public Housing \\ Contact person/ Nancy Chisholm \\ organization Department of Housing and Urban Development \\ Office of Public and Indian Housing \\ 451 Seventh St., SW \\ Washington, DC 20410
}

(202) $755-6713$

\begin{abstract}
Audience:
Public housing authorities (PHAs). More than 3,000 PHAs nationwide administer the public housing program, with 11,000 public housing projects, more than 1.3 million housing units, and more than 3 million occupants.
\end{abstract}

Funding:

The Budget Authority (BA) for FY 1988 for public housing was $\$ 2.6$ billion involving 1200 staff years. The program falls under the direction of the Assistant Secretary of Public and Indian Housing.

LBL was the lead laboratory to work on federally assisted housing starting in FY 1985. LBL received \$25,000 to do some work on this in FY 1986.

Description:

HUD spends $\$ 1$ billion/year for utilities in public housing projects that use twice as much energy as private sector housing. About $\$ 750$ million to $\$ 800$ million is for energy; the balance is for water. The nation could save up to $\$ 500$ million a year if we just put public housing at the same level as private sector housing, with a four-year payback on improvements.

The housing authorities invested $\$ 0.75$ billion of HUD modemization funds in energy conservation improvements during the Reagan administration. In 1985, an Abt study found that $\$ 1$ billion in energy conservation needed to be done. Several billion dollars a year need to be spent in basic modemization.

One place to get the money is the private sector. HUD public housing officials are attempting to forge linkages between the energy service companies (ESCOs) and public housing authorities (PHAs) so that performance contracting will occur. The Affordable Comfort Conference is one of the ways that HUD hopes to reach these audiences. Officials are also working with utilities to implement shared savings arrangements with PHAs.

In the early 1980s, the PHAs were allowed to keep part of the savings from energy conservation retrofits paid for by HUD plus an added incentive at the beginning: overall, they got $1 \frac{11}{2}$ times a year's savings and HUD got the rest, which was the major benefit. Under the 3-year rolling base accounting system, the average spending of 3 prior years is the baseline. Any major savings achieved 3 years ago would be dropped out. Then the PHA must maintain that level of efficiency to keep up. A 1987 amendment to Section 118 suspended the rolling base and said that the PHA could keep 100\% of the savings to pay off the energy service company under a performance contract using nonfederal funds [Note: these funds could include Community Development Block Grant (CDBG) funds that, once they were turned over to cities, are considered local funds.] HUD will regulate what the PHAs do with the rest of the savings, including what proportion of it they can keep and what they can use it for. For example, they might use the extra savings to pay back the energy service 
Problems:

Opportunities: company faster, or they might be permitted to develop something for tenants. These recent provisions make PHÄs' investment in energy conservation more desirable.

HUD is working with the American Gas Association and Edison Electric Institute to get technical support from local companies to the PHAs.

1. No absolute standard exists as to how much consumption should be. If there were a standard, a way would exist to get out of the problem posed by the performance funding system, from HUD's viewpoint.

2. Community Development Block Grant (CDBG) funds amounted to $\$ 2.9$ billion in FY 1988. However, the idea came along after CDBG came into existence that cities needed some technical assistance in deciding how to use the CDBG funds. Grants to special groups and technical assistance came from the Secretary's discretionary funds. HUD Secretary Jack Kemp's first initiative, however, was to do away with discretionary funds. There will be some technical assistance funding, but it will be released by RFP published in the Federal Register.

1. HUD could assist by promoting technical assistance for energy efficiency in public housing. HUD officials said that someone within HUD needs to take this on as a cause; it would be a full-time job. A HUD "energy champion" would play a broker role, facilitating local partnerships with nonprofit organizations, utilities, and housing authorities.

2. HUD said OBT could assist in the following ways:

- Inventory what things should be considered, key technological advances that should be used.

- Prepare materials about how to save energy.

- $\quad$ Provide expert review of HUD proposals for housing authorities to pay off capital improvement costs on energy.

- Attend conferences and meetings with the key players in the field of federally assisted housing.

- Conduct research on the durability of improvements that have already been done in HUD public housing.

- Give reports and sponsor panel discussions.

- Set up training for HUD offices, on topics such as audits. In addition, HUD and PHA staffs need training on shared savings deals; ESCOs need training about PHAs and how to select ones with whom they can work effectively. Perhaps HUD staff members could attend GSA training on performance contracting. 
- Distribute software that Lawrence Berkeley Laboratory (LBL) has developed to help PHAs analyze their utility expenses. The distribution of this software could be explored, and more distribution could be done, if the market is not saturated.

- Work through trade associations: (1) the National Association of Housing and Redevelopment Officials (NAHRO), which has regional chapters with regular programs and a conference one or two times a year (a workshop could be held at each conference); and (2) the Council of Large Public Housing Authorities (CLPHA). Somebody has to explain to the PHAs how to use ASEAM and other tools to assess energy conservation.

- Provide a resource on technical information to PHAs about what measures are available and which ones to use; HUD can inform them that high efficiency boilers exist, but the PHA has to find a contractor who carries them. They can call NATAS, but they need a combination of advice, perhaps beyond what NATAS can tell them.

3. More facilitation between OBT and HUD is needed to explore the opportunity to expand the use of energy-efficiency technologies in public housing. A team effort between OBT and HUD might be possible. 


\section{OTHER HUD PROGRAMS}

Name of program: Listed below

Contact person/

Robert P. Groberg

organization

Director, Energy Division

Office of Environment and Energy

U.S. Department of Housing and Urban Development (HUD)

451 Seventh St., SW

Washington, DC 20410

(202) $755-5504$

Mr. Groberg suggested that opportunities for improving energy efficiency in the nation's buildings through the use of OBT technologies might be enhanced through the other HUD programs. The audiences, funding problems, and opportunities attendant upon each of these programs would have to be explored in more depth in the future, including the perceptions of other HUD officials about the potential for realizing energy efficiency within these HUD programs.

In general, however, HUD programs other than public housing affect approximately 4 million units. Programs for assisted housing (items 2 and 3 below) involve $\$ 500$ million to $\$ 1$ billion in utility costs annually. In addition, each year $\$ 1$ billion and more are spent in Community Development Block Grants and Rental Rehabilitation Grants that are used for rehabilitating buildings.

The other HUD programs fall into six categories under three organizational units as follows.

\section{Assistant Secretary for Housing-Federal Housing Commissioner:}

1. Insurance Programs for Mortgages and Loans

2. Direct Loans

3. Subsidized Housing

\section{Assistant Secretary for Community Planning and Development:}

4. Community Development Block Grants

5. Rehabilitation Assistance Program

\section{President, Government National Mortgage Association (GNMA).}

These programs represent the greatest potential for energy efficiency in terms of size and possible points of leverage; however, other HUD programs may offer energy-efficiency advantages as well.

\section{Insurance Programs for Mortgages and Loans}

A. Home Improvement Insurance/Manufactured Housing. Title I insurance on home improvements and manufactured housing: $\$ 4.3$ billion Title I loans currently insured $(93,000$ new loans, 77,000 of them for property improvements and 16,000 for manufactured homes). $\$ 914$ million in commitments were issued for this insurance during FY 1988; 210 staff years were spent in the program.

B. Mortgage Insurance for Multifamily Properties. Mortgage insurance for multi-family dwellings: 1.9 million units are currently insured; in FY 1988 87,000 units were insured at $\$ 3.07$ billion; 1,030 staff years in the program. HUD also acquires multifamily projects or housing units through mortgage defaults. 
C. Mortgage Insurance for Single Family. Mortgage insurance to 1-4 unit homes: 6.5 million homeowners currently have FHA-insured mortgages; 945,000 applications from prospective buyers were received in FY 1988; 2,280 staff years in the program.

D. "HUD Homes." Single-family property disposition: HUD generally sells repossessed homes as is (no improvements). In FY 1988, there were 86,000 acquisitions and 81,000 sales. Proceeds were $\$ 3$ billion, which went back into the FHA fund; 850 staff years in the program.

\section{Direct Loans: Housing for Elderly and Handicapped}

Direct loans for the elderly; in FY 1988, 11,000 new units were funded; 3,500 loans are now in HUD's portfolio; $\$ 565$ million in loans were made. Since $1959,224,000$ units have been constructed or rehabilitated, $\$ 9.5$ billion has been loaned, and 430 staff years were spent in the program.

\section{Subsidized Housing}

A. Section 8 Lower Income Rental Assistance and Housin Voucher

Aids low-

and very low income families in obtaining clean, safe, and sanitary housing in private accommodations. Tenants pay the highest of $30 \%$ of adjusted income, $10 \%$ of gross income, or the portion of welfare assistance designated to meet housing costs. The housing must meet HUD standards and fall within the range of fair market rents as determined by HUD. Section 8 subsidized housing provides certificates and vouchers to 2.24 million households living in privately owned housing. About one-half of these units are also aided by HUD (such as Section 236 housing and housing for the elderly). During FY 1988, \$9 billion in subsidies were provided, with commitments for 5 years; 525 staff years were spent in the program.

B. Management of Privately Owned Subsidized Housing. Approximately 6,500 projects involving more than 650,000 units were subject to HUD requirements for performing energy surveys, preparing energy conservation plans, and implementing energy conservation measures. At a minimum, HUD required an owner certification that cost-effective measures have been taken to reduce utility expenses. These 6,500 projects are required to secure HUD approval for requested rent increases. HUD could take the opportunity of periodic rent increase requests to ensure that owners are complying with the energy provisions of existing laws. Also, DOE could provide technical assistance to HUD in developing effective, user-friendly methods of choosing the best retrofits for any specific building.

\section{Community Development Block Grants}

Funding is $\$ 2.9$ billion/year. Approximately 850 cities with populations over 50,000 are "entitlement cities" and receive $70 \%$ of CDBG funds directly. About 720 cities with populations under 50,000 receive funding through their states by competition. Energy efficiency is currently an objective of the CDBG program, but it is not a funding requirement. Approximately one-third of the annual funding is used for property rehabilitation. Approximately $22 \%$ of CDBG funding used for property rehabilitation went to multifamily housing. Among CDBG cities, the variety of standards and codes could be a barrier to implementing energy efficiency through the program. An opportunity could exist in the area of district heating and cooling projects.

\section{Rehabilitation Assistance Programs}

Other rehabilitation assistance programs include the Rental Rehabilitation Program, Section 312 Low-Interest Loan Program, Urban Homesteading Program (Section 810), and the Homeless Assistance Program (McKinney Act). Nationwide cooperation with DOE's Weatherization 
Assistance Program occurs only on an ad hoc basis, although an opportunity may exist for cooperation at the local level. DOE could provide improved audit techniques, technical assistance in creative financing, educational materials for property owners and program staff, and manuals and handbooks.

\section{Government National Mortgage Association (GNMA-"Ginnie Mae")}

GNMA guarantees payments on securities that private lenders issue; pools loans of FHA and VA and enables them to sell to investors so capital goes back into the housing market. The purpose of this program is to attract nontraditional investors into the residential mortgage market by offering high-yield, risk-free, govemment-guaranteed securities without the servicing obligations of a mortgage loan portfolio. $\$ 333$ billion is in outstanding guaranteed securities; $\$ 57$ billion in guarantees were issued in FY 1988; 50 staff years in the program.

GNMA is trying to encourage special treatment for energy efficiency in mortgages, which is related to interest in home energy rating systems.

\section{Summary}

DOE has the capability to support HUD in developing and implementing conservation and renewable energy activities. DOE can assist HUD programs in incorporating energy efficiency and renewables measures, performing energy surveys and audits, providing training in shared energy savings and other relevant matters, monitoring program effectiveness, and developing standards.

Follow-up discussions and further definition of areas of opportunity by the cognizant HUD and DOE program managers are needed if the significant energy-efficiency potential thus far identified within HUD's programs is to be realized. 


\section{NATIONAL INSTITUTE OF STANDARDS AND TECHNOLOGY (NIST)}

Name of program: Office of Technology Commercialization (OTC)

Contact person/

Robert Chapman, Acting Director

organization:

Office of Technology Commercialization

National Institute of Standards and Technology

Gaithersburg, MD 20899

(301) $975-2723$

Fax: (301) 975-2128

Audience:

U.S. industry

Funding:

Total OTC funding in FY 1990 is approximately $\$ 3$ million. About $40 \%$ of NIST funding comes from other government agencies, with approximately 500 to 600 contracts. Major contractors are NASA, DOD, and DOE. About 100 agencies are involved, including the Environmental Protection Agency (EPA), the Department of Health and Human Services (HHS), the U.S. Postal Service (USPS), and the National Research Council (NRC). Approximately 5\% to $10 \%$ of the NIST budget comes from fees for services. For example, NIST sells standard reference materials and has calibration and laboratory accreditation services. About one-half of NIST's budget is from Congressional appropriations.

Description: $\quad$ OTC is currently doing the following:

- Surveying what NIST is doing that may have potential for industry. -

- Letting industry know that it exists.

- $\quad$ Getting industry to use it.

- Working cooperatively with other organizations that are making technologies known to users (e.g., both federal and nonfederal).

The Omnibus Trade and Competitiveness Act of 1988 changed the agency's name from National Bureau of Standards (NBS) to NIST and gave the agency a new set of mandates:

Survey the states to discover how they are using technology as part of an economic development program. This survey identified about 230 organizations spending $\$ 620$ million/year on economic development programs. The survey asked how technologies are used. Some of the patterns discovered include incubator facilities, centers of excellence at universities, and methods of engineering extension education.

- Hold a series of workshops in the states to inform them about federal resources. The state people needing to attend these workshops are located in a variety of organizations. For example, Virginia has a Center for Innovative Technology. Ohio has the Ohio Technology Transfer Organization (OTTO), which is part of the larger Thomas Edison program. Pennsylvania has a Technical Assistance Program under Pennsylvania State College, which is part of the Ben Franklin partnership.

- Develop an Advanced Technology Program to accelerate the commercialization of new manufacturing techniques by U.S. business, particularly by small entrepreneurial firms. 
Problems:

Opportunities:
- Expand the Energy Related Inventions Program (ERIP) (see the description of that program) from simply energy inventions to all inventions, with the exception of frivolous things like toys and cosmetics. Recommendations about this expansion have gone back to Congress via the Department of Commerce (DOC).

- Expand user-oriented industrial services, such as national standard reference data and materials.

1. No one industry has the resources to solve technology commercialization problems alone, and the federal government can seed projects to tackle these problems; industry could eventually take over. Antitrust laws might have to be relaxed so that industries can work together.

2. NIST-OTC has not yet completed an evaluation of how OBT could assist in its mission to improve the competitiveness of U.S. industry, both in terms of (1) providing innovative technology, which would create new business opportunities, and (2) improving the productivity of the manufacturing sector through reducing energy operating costs.

1. NIST has good rapport with industry; it sets standards and has credibility; it appears to be good at transferring technological information. Working with NIST to transfer energy-efficient technologies through economic development organizations at the state level, and possibly to link state energy offices with state economic development offices, could be a prime opportunity.

2. The OTC has an annual budget of $\$ 1.3$ million earmarked for technology extension, including workshops, seminars, and grants to states to foster technology commercialization and economic development.

3. The OTC has signed a memorandum of agreement with the Federal Laboratory Consortium (FLC) (see the description of the FLC) to reach out to businesses and conduct workshops for state technical and economic development organizations. The FLC will inform state people about how to gain access to the federal laboratories. At these workshops, building energy materials could be available for display and distribution.

4. The OTC operates a clearinghouse on state and local initiatives, in cooperation with the DOC's technology administration, through its State Technology Extension Program. The OTC could train the trainers of the state extension staffs on where to get information on energy-efficient technologies.

5. Ties already exist with NIST through the Center for Building Technologies (see the description of that program). OBT could undertake a pilot project to explore the feasibility of such a linkage between OBT and the NIST OTC. 


\section{NATIONAL INSTITUTE OF STANDARDS AND TECHNOLOGY (NIST)}

Name of program: Center for Building Technology (CBT)

Contact person/ organization:

Audience:

Funding:

Description:
James E. Hill, Chief

Building Environment Division

Center for Building Technology

National Institute for Standards and Technology

Gaithersburg, MD 20899

- $\quad$ ASHRAE and ASTM, consensus standards

- Researcher exchange program, with approximately 10 industry-paid staff members from industry on site at a time

- $\quad$ Product manufacturers

$\$ 11$ million/year; ,112 staff members

The CBT's mission is to increase the usefulness, safety, and economy of buildings through the advancement of building technology and its application to the improvement of building practices. Its objectives are to

1. Increase the productivity and safety of building construction by providing technical bases for improved structural and earthquake design criteria. (Examples: structural loads, wind engineering, structural analysis, nondestructive evaluation methods, full-scale structural performance, failure analysis and investigation, earthquake engineering.)

2. Reduce building costs and increase building quality by providing technical bases for selecting the most cost-effective materials. (Examples: protective coatings, performance of roofing systems, service life prediction, quality assurance of laboratories, cement hydration.)

3. Reduce the cost of designing and operating buildings and increase the international competitiveness of the U.S. building industry by providing modeling, measurement, and test methods needed to (1) use advanced computation and automation effectively in construction, (2) improve the quality of the indoor environment, and (3) improve the performance of building equipment. (Examples: refrigerant mixtures, mechanical systems and controls, test procedures for energy appliances, indoor air quality, heat transfer, solar equipment, computer-integrated construction, lighting, building security.)

NIST has no direct plan to assist U.S. industry other than through its programs. NIST has developed a reorganization plan and has not yet put it into effect. (A search for a new director is currently under way.) The Office of Technology Commercialization is planning how to carry out NIST's new legislative mandates. 
Opportunities:

1. CBT works with ASHRAE and ASTM, as do other OBT-funded groups and national laboratories. CBT staff members write chapters for the ASHRAE Handbook of Fundamentals. In this regard, they are already carrying out a technology transfer function for OBT.

2. The National Research Council of Canada in Ottawa produces a periodical, the Canadian Building Digest, that Dr. Hill thinks is extremely useful to practitioners in Canada. It publishes the viewpoint of the local builder, and it synthesizes the research and translates it for the general contractor, giving practical guidance on what to do.

3. The CBT Building Technology Symposia series has been running for 17 to 18 years, with eight or nine symposia/year. Started originally for federal agencies, the free symposia are one-day presentations on state-of-the-art technologies in particular areas. Past topics have included

- Experiences of federal agencies with computer graphic systems

- Application of artificial intelligence to construction

- Advances in painting technology and practice

Building security

- $\quad$ Earth orbiting structures

- Moisture research problems in buildings

Design of structures for explosive threats

- Diagnostics and maintenance of mechanical systems in buildings.

Between 50 and 200 people attend; most of them are federal agency staff members. CBT maintains a mailing list to announce the seminars. Volunteer staff time is used to organize the seminars, but with a small amount of funding and some work with the laboratories, the symposium series could be increased in significance. OBT might want to explore whether the attendees at these seminars are decision makers in their respective organizations, actually affecting building design or other ways in which energy is used. 
TRADE AND

PROFESSIONAL ORGANIZATIONS 


\title{
NATIONAL ASSOCIATION OF REGULATORY UTILITY COMMISSIONERS (NARUC)
}

\author{
Name of program: National Association of Regulatory Utility Commissioners \\ (NARUC) \\ Contact person/ \\ organization: \\ Michael Foley \\ Director of Financial Analysis \\ National Association of Regulatory Utility Commissioners \\ 1102 ICC Building \\ Constitution and 12th, NW \\ P. O. Box 684 \\ Washington, DC 20044-0684
}

Audience:

Funding:

Description:

Problems:
(202) $898-2200$

NARUC membership includes 220 state public utility commissioners plus 100 Canadian and federal officials. The commissioners regulate, in addition to utility companies, telephone, water, gas, insurance, banking, and taxicab industries.

NARUC's budget comes from member utility commissions. The federal government provides office space in lieu of dues from federal commissioners. BCS funds NARUC's Least-Cost Utility Planning (LCUP) project at $\$ 135,000 /$ year.

NARUC serves as the commissioners' eyes and ears in Washington, D.C., keeping them abreast of bills, rules, and regulations being developed in the capitol and representing their interest on Capitol Hill and in the courts.

NARUC also serves as a source of information for the commissioners through its newsletter, annual conferences, and special conferences.

NARUC committees also develop commission policies on an array of topics. For example, the Energy Conservation Committee develops NARUC policy in the energy conservation arena and presents resolutions to the full membership. The committee's membership includes 20 commissioners and 25 staff people. The committee chair is Mary Lou Munts of the Wisconsin Public Service Commission, and the cochairs of the staff group are Rick Morgan (District of Columbia Public Service Commission) and Mary Kilmarx (Rhode Island Public Utilities Commission).

1. Utility regulation involves complex issues, and commissioners have a difficult time staying abreast of the technical information they need. Since most commissioners serve for only 4 years, this compounds the problem.

2. An inspiring speaker like Amory Lovins might give a brilliant presentation, but afterward, the commissioners are unsure about what to do next. They lack specific information about, for example, the names of the manufacturers of energy-efficient light bulbs, where these can be obtained, and whether people will use them. The same is true of advanced windows and the other energy-efficiency technologies. 
Opportunities:

1. NARUC publishes a weekly Bulletin for which timely, brief articles could be prepared on energy efficiency in buildings, utility regulation to foster energy efficiency, and related topics.

2. Each year, NARUC sponsors a winter meeting in Washington the last week of February, a summer meeting on the West Coast the third week of July, and an annual convention that travels in November. In addition, NARUC's five regional groups (Northeast, New England, Western, MidAmerica, and Southeastem) meet once a year in the late spring. Each of these meetings could be a venue for speakers on energy efficiency in buildings and how commissioners can affect its use.

3. DOE could provide information to the Energy Conservation Committee that would help in the debate among commissioners about the best ways to solve energy problems.

In summary, the NARUC commissioners and staff people want to know the latest developments in lighting, windows, and other technologies. To promote energy conservation in utility planning, they must have solid evidence of the performance of these technologies and of effective energy service delivery programs.

The latest work under the LCUP project is suggesting that utilities will foster least-cost planning when it is in their interest to do so. LCUP includes both supply and demand technologies and fosters cost (not necessarily energy) reduction, although frequently the two overlap. 


\title{
NATIONAL ASSOCIATION OF STATE ENERGY OFFICIALS (NASEO)
}

\author{
Name of program: National Association of State Energy Officials (NASEO) \\ Contact person/ \\ organization: \\ Frank Bishop, Executive Director \\ NASEO \\ 122. C Street, NW, Suite 810 \\ Washington, DC 20001
}

(202) 639-8749

(Fax: 202-783-2247)

\begin{abstract}
Audience:
Representatives of 49 state and territorial energy offices. Usually, the member is the person responsible for SECP, EES, ICP, and in some cases the WAP and LIHEAP programs.
\end{abstract}

Funding:

Funding is through state dues and affiliate and associate memberships.

Description:

NASEO's major function is to update the states on events and activities in Washington and to act as a liaison. NASEO is collecting information from the states about the projects for which they have used oil overcharge funds.

NASEO publishes the Quarterly Newsletter and sponsors an annual meeting and a winter meeting in Washington, D.C., each year.

NASEO committees include energy emergencies, integrated energy planning, SECP, govemment affairs, appliances and building standards, R\&D, electrical siting, and global warming. Committee chairs select members.

Problems:

1. SEOs are not getting sufficient technical information from the national laboratories. The two types of organizations lack sufficient communication, even though a need exists for them to talk with each other. States need and want to know which technologies work, both for energy efficiency and for economic development. SEOs want to do demonstration projects to transfer workable technologies.

2. States are concerned about delivering the OTFA programs and about economic development. The natural overlap between these two activities, along with concems for environmental protection, has not yet been exploited.

Opportunities: $\quad$ 1. A linkage directly from OBT to NASEO would be effective, as would be a linkage from OBT to OTFA to NASEO. Any linkage from OBT to the national laboratories to NASEO would be less effective, because these players are less well known in the NASEO community. Immediately available opportunities are for speakers at NASEO meetings and articles for the NASEO newsletter.

2. NASEO looks forward to working more closely with the national laboratories. NASEO is not hearing what the national laboratory projects are, and it would like to know this. NASEO is receiving CADDET newsletters but not necessarily information on what the national laboratories are doing. SEO staffs want "early waming" about technologies under development. 
3. States need to deal effectively with buildings they own. The analysts with the SEOs certified to perform technical analyses on commercial buildings are the target audience that needs to know the technologies to recommend. For example, in Mississippi, 22 engineers are certified to conduct technical analyses for ICP. Their firms need to know new products and technologies to improve the efficiency of buildings. The state ICP director supervises the engineer who reviews the technical analysis performed by the private engineers.

4. DOE staff members could speak at NASEO's regional meetings about the new types of energy-efficiency products, tools and practices for schools, hospitals, and congregational buildings, for example. They can't recommend the products, but they can recommend the technologies.

5. S. 247, a bill under consideration to amend the Energy Policy and Conservation Act, establishes an "Engineering Extension Service" to aid small and start-up businesses in discovering useful and practical information relating to manufacturing and commercial production techniques and costs, and other functions. The act states that the service shall provide instruction, referrals, and practical demonstrations in commercializing an entrepreneur's idea or a technology developed by any of the national laboratories or other sources. This is intended to assist the economic development of states. This service, if established, could also be an important technology transfer mechanism. 


\section{THE U.S. CONFERENCE OF MAYORS}

\author{
Name of program: \\ Contact person/ \\ organization:
}

\author{
Audience: \\ Funding: \\ Mayors of cities with populations of 30,000 and more (about 900 cities)

$$
\$ 3.8 \text { million (estimate) }
$$

Description:
The U.S. Conference of Mayors

\author{
J. Thomas Cochran (or Kay Scrimger) \\ Executive Director \\ The United States Conference of Mayors \\ 1620 Eye Street, NW \\ Washington, DC 20006
}

(202) $293-7330$
The U.S. Conference of Mayors is the official organization representing mayors of cities with a population of 30,000 or more. Throughout its 57-year history, the Conference has developed a record of analysis and action on a broad array of urban issues. It has eamed credibility among mayors and their staffs and has access to an extensive network of urban decision makers and leaders, not only in city halls but also in the private sector, foundations, neighborhood organizations, and other parts of cities.

The Conference holds two major meetings each year: the Annual Conference of Mayors (annual meeting) in June, and the winter meeting in January. It publishes a semimonthly newspaper, U.S. Mayor.

The Conference will form a Mayors' Advisory Group on national laboratories and technology transfer. It will select, with FLC guidance, six cities to participate in specific demonstrations of the application of various laboratory technologies. In three additional cities, experiments will be conducted in using "technical volunteers" from local national laboratories to assist in resolving community technical problems.

The Conference is planning to develop an ongoing program to publicize available new technologies to city governments.

The U.S. Conference of Mayors provides a central mechanism for deliberation and consensus building on urban policy among its cities, for articulation of that policy to the govemment and people of the nation, and for action to assist cities in implementing programs and policies that benefit urban America. Its network consists of more than 900 cities, as well as an affiliate membership organization composed of major corporations, organizations, and others interested in urban development. U.S. Mayor is distributed to more than 5,000 persons in addition to the Mayors' network. Numerous newsletters, legislative bulletins, and other communication vehicles are also used. 
Problems:

Opportunities:
None identified.

1. DOE could cosponsor a workshop with the Conference focusing on energy efficiency in city buildings targeted to mayors and building officials.

2. DOE staff members give a presentation at the Conference's Annual Meeting of Mayors. 


\title{
NATIONAL ASSOCIATION OF HOME BUILDERS (NAHB)
}

\author{
Name of program: National Association of Home Builders (NAHB) \\ Contact person/ \\ organization: \\ Thomas A. Farkas \\ Technology and Codes Department \\ NAHB \\ 15th and M Streets, NW \\ Washington, DC 20005
}

(202) 822-0229

(800) $368-5242$

Audience:

157,000 members, including 50,000 home builders and others in related occupations such as designing buildings and supplying building materials and equipment. NAHB represents most of the major builders in the United States; there are 800 affiliated state and local Home Builder Associations (HBAs).

Funding:

Funded by member dues. NAHB has about 290 full-time staff members; the NAHB National Research Center (see the description of this organization), and the Home Builders Institute (with 50 staff members in Washington and 500 around the nation) are wholly owned subsidiaries.

Description: $\quad$ NAHB is the trade association for the building industries, performing lobbying functions at the federal, state, and local levels. It is linked with the Home Builders Associations in each state.

The Home Builders Institute (HBI) is a wholly owned subsidiary with a Graduate Builders Institute that offers courses and seminars. Energy is one of 12 educational modules required to graduate from the Institute.

Information flows from NAHB to the $800+$ HBAs at the state and local levels, each of which has its own newsletters, seminars, meetings, and educational programs.

The NAHB has various councils, including the Commercial Buildings Council, the Multifamily Buildings Council, the National Council for the Housing Industry, and the Remodelers Council, each of which has interests in energy efficiency. These councils have their own newsletters, meetings, and publications targeted toward their special interests. Besides the councils, NAHB has an energy committee that follows energy matters, as do a number of state and local HBAs, and a Standing Committee on Research that follows research issues.

NAHB holds three board meetings a year with educational programs at the annual convention in January (held in 1990 in Atlanta). At each board meeting, an education program covers energy technology updates. Speakers are invited to discuss their latest findings, including national laboratory speakers. Board meetings are attended by 2,000 to 2,500 people.

NAHB has a bookstore and a catalog of publications. The organization has credibility and leads as much as follows its members, who look to NAHB to provide them with information. Every aspect of buildings is covered. 
Problems:

Opportunities:
1. The barriers to technology adoption should be analyzed in a technologyspecific way and then remedial measures should be taken. General analysis is not adequate to solve the problem.

2. Personnel tumover within OBT and NAHB can interfere with effective ongoing liaisons to enhance technology transfer.

1. Because of its close ties with the NAHB National Research Center, NAHB relies somewhat more on results emerging from the Center than from other sources. These results are transferred somewhat more readily than others. Joint projects between the laboratories and the Center would produce results more rapidly transferred through NAHB.

2. A mechanism is needed to evaluate which energy-efficiency technologies could most effectively go through the NAHB network. Both OBT and NAHB would be represented.

3. NAHB is developing a program involving standards development, builder training and education, certification and quality assurance, research, and promotion and marketing. NAHB would offer the program so that a builder could become registered as an NAHB energy program builder. The houses they built would be certified as built to a standard. A quality assurance program would back up the builder and the house. NAHB would promote and market both the builder and the house as being built to higher energy-efficiency levels. The program's framework would be at the national level, with pilot programs at the state level to enhance implementation.

The key to this program is national and local partnerships with utilities and mortgage lenders, realtors, appraisers, and others. The partnerships would be started at the national level.

The program would yield a group of builders willing to build energyefficient housing and trained in doing so. In the beginning, they would be avant garde builders; however, over time, they would become opinion leaders and could introduce existing and new technologies. They could become an important conduit for energy-efficiency technologies. If the program is to be implemented, it may require a significant investment on the part of the federal govemment. 


\title{
NAHB NATIONAL RESEARCH CENTER
}

Name of program: National Association of Home Builders (NAHB)

National Research Center

Contact person/

Liza K. Bowles, Vice President

organization:

NAHB National Research Center

400 Prince Georges Center Boulevard

Upper Marlboro, MD 20772-8731

(301) $249-4000$

\begin{abstract}
Audiences:
The NAHB itself, and the 157,000 members it represents (including 50,000 builders); client organizations, such as federal agencies; product manufacturers

Funding:

Funded by clients for research projects; approximately 50 full-time staff members

Description:

The Center is a wholly owned not-for-profit subsidiary of the NAHB, with a threefold mission: (1) conduct applied research on buildings technology, (2) promote quality standards in building materials and construction, and (3) help maintain the U.S. building industry's competitive position.
\end{abstract}

The Center is working on an OBT-funded project with A.D. Little (ADL) and Massachusetts Institute of Technology (MIT) to identify future product and process technologies and develop a methodology to recognize those with the greatest potential value using the NAHB to get them to the marketplace as soon as possible. MIT is working on product technologies and ADL on process technologies, changes in tools and equipment, changes in materials, and the movement from on-site to off-site fabrication of building components and subsystems.

The Center has a Research Home Park about a mile away on 51 acres. One home exists and another is under construction; 25 homes will eventually be constructed there. This facility allows NAHB to test technologies, document results in major trade publications, and display them to 2,500 builders attending the annual spring board meeting in Washington.

The Center's Laboratory Services Division operates a major certification and labeling program for products such as thermal insulation and plastic bathroom fixtures. Products are prominently marked with the Center's label. Nationally recognized tests are performed to ensure that the product meets the specifications issued by the manufacturer.

Problems:

1. The industry doesn't have an effective way to deal with product failures. Builders and manufacturers obviously want an effective process for dealing with product failure. If recognized processes are not established, standards may become quite stringent to compensate. This would be a strong impediment to investment in building industry innovations.

2. The Center has no intemal resources for projects, relying on extramural funding. 
Opportunities:

1. The opportunity to use the Research Home Park to display energy-efficiency technologies to the many builder visitors is unique; the Park is a resource that DOE could use in its technology transfer efforts.

2. The National Concrete Masonry Association house being designed now has a strong passive-solar component with storage and will be instrumented for major thermal and indoor air quality testing. This represents an opportunity for potential collaboration.

3. The Research Home Park also represents an opportunity to field test technologies and products that are almost ready for commercialization.

4. Builder focus on technologies is a good way to get feedback for the R\&D and technology transfer programs.

5. The Center writes articles about buildings technologies for a variety of magazines, including Nation's Building News, Professional Builder, Builder, Journal of Light Construction, Energy Digest, Energy Design Update, and Fine Home Building.

6. The Center presents programs at the NAHB annual meeting on advances in buildings technologies.

7. The Center can collaborate in buildings energy-efficiency research with the national laboratories and other organizations. In addition, the Center could help play a broker role to translate research done at the national laboratories into information products and processes useful to buildings industries people. 


\section{NATIONAL INSTITUTE OF BUILDING SCIENCES (NIBS)}

Name of program: National Institute of Building Sciences

Contact person/ organization:

Audience:

Funding:

Description:
David Harris, President

National Institute of Building Sciences

1201 L Street, NW, Suite 400

Washington, DC 20005

(202) $289-7800$

Fax: (202) 289-1092

NIBS membership includes representatives from building community trade, professional, and labor organizations; private and public standards, codes, and testing bodies; public regulatory agencies; and consumer groups. NIBS membership, with its three affiliated councils, exceeds 800 .

NIBS has formal ties with many public and private interest groups, including all levels of government, consumers, code officials, architects, engineers, builders, developers, product manufacturers, and standards organizations.

NIBS' annual budget ranges from $\$ 3$ to $\$ 4$ million. Funding sources for NIBS' activities include general and restricted support grants from private sources, membership dues, income from sales of services and publications, Congressional appropriations that match NIBS' private income, contracts, and grants from federal and other agencies.

NIBS was established in 1976 as a nongovemmental, nonprofit 501(c)(3) corporation in response to P.L. 93-383. NIBS was conceived as a public/private partnership to serve as an impartial forum to resolve technical and regulatory issues facing the nation's housing and building process.

In accordance with the authorizing legislation, NIBS' four major functions involve

- Developing performance-based criteria, standards, and other technical provisions for evaluating building products, systems, and components.

- Facilitating the use of the performance criteria in evaluation, including certification, listing, and labeling programs.

- Conducting investigations to carry out the first two functions.

- Collecting and disseminating related information.

Current programs include federal design and construction criteria management and dissemination; guidelines for radon, lead-based paint, asbestos, wood protection, and building seismic safety; foreign influences; modular housing; building thermal envelopes research; and fire hazards. 
Problems:

1. NIBS depends on outside funding and has limited resources to develop or transfer information without outside funding.

2. Environmental issues, such as indoor air quality, are developing rapidly and are placing new demands upon the building community.

3. The building community is composed of so many different sectors that the federal govemment has difficulty interfacing directly with each of the organizations representing the diverse sectors.

4. Better coordination and communication are needed to continue to improve standards, codes, regulations, and practices governing technology evaluation, development, and application.

Opportunities:

1. NIBS can assist in analyzing barriers to and suggesting solutions for the promulgation of information to the buildings community. Issue papers developed on these problems go to the councils for review, which strengthens such papers.

2. NIBS can reach a broader cross section of the building community than other organizations can.

3. NIBS has developed, maintains, and distributes the "Construction Criteria Base" (CCB), a 250,000 page compilation of technical building infornation on an automated CD-ROM based system. CCB includes building specifications, standards, codes, and other technical criteria. Automated design tools (applications software and technical information) and other software are included. Nine hundred current subscribers, growing at the rate of 30 to 40 subscribers a month, are paying $\$ 1,000 /$ year for CCB information. The CCB can be used as a vehicle to transfer infornation and applications software programs to subscribers, predominantly design professionals.

4. NIBS can develop criteria on how specific technologies are to be installed and how they should perform and can relate their use to the construction "chain"--designers, specification writers, contractors, facility managers, developers, and building owners. Developing criteria is an essential yet expensive step. Once the criteria are developed, the information can be distributed through the CCB, an efficient dissemination medium.

5. NIBS can help in supporting and coordinating national and international product testing and certification activities affecting the U.S. building process.

6. NIBS can serve as a forum to facilitate cooperative programs among government agencies and the private sector, both domestically and internationally. 
BUILDING THERMAL ENVELOPE COORDINATING COUNCIL (BTECC)

Name of Program: Building Thermal Envelope Coordinating Council (BTECC)

Contact:

Bruce Vogelsinger

National Institute of

Building Sciences

1201 L Street, N.W.

Washington, DC 20005

Erv Bales

New Jersey Institute of

Technology

School of Architecture

323 High Street

(202) 289-7800

Fax: (202) 289-1092

Newark, NJ 07102

Audience:

Members of building community sectors with an interest in building envelope research, design, and operation. Includes product manufacturers, design professionals, researchers, academia, codes and standards, government agency, labor, and construction representatives.

Funding:

Sources of funds for BTECC activities include general support grants, dues, and contracts from public and private organizations. BCS had funded some BTECC activities since FY 1985.

Description: $\quad$ BTECC was established as an independent council under the auspices of the National Institute of Building Sciences to coordinate industry and govemment R\&D efforts in building thermal envelope materials and technologies. Developing periodic national plans for the building envelope industry is a principal activity. BTECC focuses on research and technical activities related to

Developing new knowledge of improved building energy-efficient materials, components, and systems;

- Modeling thermal envelope systems and subsystems;

- $\quad$ Stimulating use of new and existing technology and technology verification projects; and

- Coordinating thermal envelope and service system interfaces.

Problems:

The solar industry and others have information on such topics as heat and mass transfer and daylighting that architects and engineers may not have. The research and applications communities sometimes have difficulty obtaining the information they need.

Opportunities: $\quad$ A tie has already been established between OBT and BTECC. With a small amount of support, BTECC could accomplish a great deal of technology transfer for OBT. BTECC has established research-coordinating committees composed of industry, govemment, and university representatives. These committees offer a substantial opportunity for leveraging. BTECC nuns periodic workshops, primarily with DOE funds, meets several times a year, and tackles specific projects on an as-needed basis. 


\begin{tabular}{|c|c|c|c|}
\hline $\begin{array}{l}\text { Document Control } \\
\text { Page }\end{array}$ & $\begin{array}{l}\text { 1. SERI Report No. } \\
\text { SERI/TP-260-3716 }\end{array}$ & $\begin{array}{l}\text { 2. NTIS Accession No. } \\
\text { DE } 90000346\end{array}$ & 3. Recipient's Accession No. \\
\hline \multirow{2}{*}{\multicolumn{3}{|c|}{$\begin{array}{l}\text { 4. Title and Subtitle } \\
\text { Transferring Building Energy Technologies by Linking } \\
\text { Government and Private-Sector Programs }\end{array}$}} & $\begin{array}{l}\text { 5. Publication Date } \\
\text { July } 1990\end{array}$ \\
\hline & & & 6. \\
\hline \multicolumn{3}{|l|}{$\begin{array}{l}\text { 7. Author(s) } \\
\text { B. C. Farhar }\end{array}$} & 8. Performing Organization Rept. No. \\
\hline \multirow{2}{*}{\multicolumn{3}{|c|}{$\begin{array}{l}\text { 9. Performing Organization Name and Address } \\
\text { Solar Energy Research Institute } \\
1617 \text { Cole Boulevard } \\
\text { Golden, Colorado } 80401-3393\end{array}$}} & $\begin{array}{l}\text { 10. ProjecUTask/Work Unit No. } \\
\text { AS } 925440\end{array}$ \\
\hline & & & $\begin{array}{l}\text { 11. Contract (C) or Grant (G) No. } \\
\text { (C) } \\
\text { (G) }\end{array}$ \\
\hline \multirow{2}{*}{\multicolumn{3}{|c|}{ 12. Sponsoring Organization Name and Address }} & $\begin{array}{l}\text { 13. Type of Report \& Period Covered } \\
\text { Technical Report }\end{array}$ \\
\hline & & & 14. \\
\hline
\end{tabular}

15. Supplementary Notes

16. Abstrac: (Limit: 200 words)

This report summarizes the results of an interlaboratory planning effort in support of the U.S. Department of Energy's (DOE's) Office of Building Technologies (OBT). The study was carried out by a Technology Transfer Advisory Group composed of representatives from DOE and four national laboratories to explore ways to improve technology transfer related to energy efficiency in buildings. As part of this effort, representatives of 22 programs and organiątions were interviewed about their perceptions of the potential for transferring energy efficiency in buildings through active linking with OBT programs. The report docüments technology transfer opportunities defined by these organizations. The Advisory Group concluded that OBT could pursue technology transfer linkages inmediately with the Federal Energy Management Progran, U.S. Housing and Urban Development Programs, the National Association of Home Buildere and the National Institute of Standards and Technology. Other opportunities exist within DOE's Office of Technical and Financial Assistance, the National Appropriate Technology Assistance Service, the National Association of Regulatory Utility Commissioners, and the National Association of State Energy Officials. The Advisory Group recommended that DOE continue to explore the potential for linking with other progra $=$ and organizations chiefly involved in information and technology transfer.

17. Document Analysis

a. Descriptors

Solar Energy Research Institute; US DOE; energy efficiency ; buildings ; technology transfer; information dissemination

b. Identifiers/Open-Ended Terms

c. UC Categories

233

18. Availabılity Statement

National Technical Information Service U.S. Department of Commerce

5285 Port Royal Road

Springfield, Virginia 22161

\begin{tabular}{|l|}
\hline $\begin{array}{l}\text { 19. No. of Pages } \\
72\end{array}$ \\
\hline $\begin{array}{c}\text { 20. Price } \\
\text { A04 }\end{array}$
\end{tabular}

